\title{
Pandemic, Plague, Pestilence and the Tropics: Critical Inquiries from Arts, Humanities and Social Sciences
}

\author{
Anita Lundberg \\ https://orcid.org/0000-0002-0271-4715 \\ James Cook University, Australia \\ Kalala Ngalamulume \\ https://orcid.org/0000-0003-3867-0539 \\ Byrn Mawr College, USA \\ Jean Segata \\ https://orcid.org/0000-0002-2544-0745 \\ Federal University of Rio Grande do Sul, Brazil \\ Arbaayah Ali Termizi \\ https://orcid.org/0000-0002-9626-1701 \\ University Putra Malaysia, Malaysia \\ Chrystopher J. Spicer \\ https://orcid.org/0000-0003-1369-4497 \\ James Cook University, Australia
}

\begin{abstract}
The Tropics have long been associated with exotic diseases and epidemics. This historical imaginary arose with Aristotle's notion of the tropics as the 'torrid zone', a geographical region virtually uninhabitable to temperate peoples due to the hostility of its climate, and persisted in colonial imaginaries of the tropics as pestilential latitudes requiring slave labour. The tropical sites of colonialism gave rise to urgent studies of tropical diseases which lead to (racialised) changes in urban planning. The Tropics as a region of pandemic, plague and pestilence has been challenged during the COVID19 pandemic. The novel coronavirus did not (simply) originate in the tropics, nor have peoples of the tropics been specifically or exclusively infected. The papers collected in this Special Issue disrupt the imaginary of pandemics, plague and pestilence in association with the tropics through critical, nuanced, and situated inquiries from cultural history, ethnography, cultural studies, science and technology studies, Indigenous knowledge, philosophy, anthropology, urban studies, cultural geography, literature and film analyses, and expressed through distinctive academic articles, poetry and speculative fiction.
\end{abstract}

Keywords: pandemic, plague, pestilence, epidemics, Covid-19, tropics

eTropic: electronic journal of studies in the tropics publishes new research from arts, humanities, social sciences and allied fields on the variety and interrelatedness of nature, culture, and society in the tropics. Published by James Cook University, a leading research institution on critical issues facing the world's Tropics. Free open access, Scopus Listed, Scimago Q2. Indexed in: Google Scholar, DOAJ, Crossref, Ulrich's, SHERPA/RoMEO, Pandora. ISSN 1448-2940. Creative Commons CC BY 4.0 free to download, save and reproduce. To cite, include: Author(s), Title, eTropic, volume, issue, year, pages and DOI: http://dx.doi.org/10.25120/etropic.20.1.2021.3802 


\section{Wildly Infectious}

he Tropics have long been associated with exotic diseases and epidemics. This historical imaginary arose with Aristotle's notion of the tropics as the 'torrid zone', a geographical region virtually uninhabitable to peoples of the northern temperate regions due to the hostility of its climate; it persisted in colonial imaginaries of the tropics as pestilential latitudes requiring slave labour. The tropical sites of colonialisms gave rise to urgent (western) studies of tropical diseases which lead to changes in architecture and urban planning, to the creation of institutes of tropical medicine and the subjugation of Indigenous knowledge and science.

The tropics as a region of pandemic, plague and pestilence has been challenged during the global pandemic of the novel coronavirus disease COVID-19. The new virus neither (simply) originated in the tropics, nor were the tropical countries of the world specifically or exclusively infected. Tropical countries have been impacted by, and responded to, the novel coronavirus in diverse ways. This disrupts the imaginary of pandemics, plagues, pestilence in association with the tropics, and calls for critical, nuanced, and situated analyses.

Indeed, critiques of the notion of the Tropics as wildly infectious sites of pandemic, plague and pestilence already have a long history promulgated through the arts, humanities and social sciences. Even a brief overview of a small selection of these articulations alerts us to their diversity, as well as to how infectious diseases are likewise embroiled within diverse natural, cultural and social tropicalities.

In Thai director Apichatpong Weerasathakul's 2004 film Tropical Malady [Satpralat; monster], the malady refers to malaria and its deadly tropical fevers; but it also alludes to the plagued human soul divorced from its own animality; and moreover to how love is malarial, an illness of delirious desire. This sense of delirium is created through the tropical details of the jungle floor - "its paw-prints, twigs, dead leaves, snail shells, flyblown turds, leeches and most of all mud" (Clarke in Creed, 2011, p. 139). The viewer too suffers a malady of tropicality as they become lost in shadowy jungles, embroiled in human-animal shape-shifting, and stalked by a ghostly tiger-shaman. Here the audience encounters the more-than-human world in the intertwining of human-animaljungle-insect-disease-mud.

Vampire myths have for centuries feasted on the bloody settings of epidemics and violent racial histories. The Tropical Gothic vampire genre has been well documented regarding references to the fear of the other, the mixing of cultures, races and species, and to sexuality and the dangers of mixed blood and bodily fluids. The tropical milieu 
of New Orleans, with its raucous vieux carré, languorous plantation mansions, mysterious bayous, ethnic and linguistic heterogeneity and anxieties over inter-racial liaisons formed the fertile (play)ground for the contemporary Gothic novels, Interview with a Vampire (Rice, 1979), The Southern Vampire Mysteries, (Harris, 2009), the TV series True Blood (Ball, 2008-2014) and the video game Vampire the Masquerade: Bloodlines (2004). ${ }^{1}$ In the video game, vampires are grouped according to clans - from the fashionable and eroticised "Toreador" nightclubbing vamps, to the ostracised and primitivised "Nosferatu" sewer dwellers. New Orleans was established as the capital of the French Colony of Louisiana in 1723 at a time of European vampire hysteria. The city has always been immersed in its steamy climate and surrounding watery landscape of bayous - impacted by the deathly forces of hurricanes and epidemics of tropical disease. Mosquito vector diseases were particularly prominent in its history with epidemics of yellow fever causing deaths in the tens of thousands. Mass deaths from fever were blamed on evil spirits entwined with foreigners' bodies and their cultural practices. Horrors came from elsewhere - Europe, Haiti, Africa - to enter the city and contaminate the populace. The pestilence of vampires mirrors the pestilence of epidemics and is further connected with the racial brutality of tropical plantations and the slave trade (Dillon \& Lundberg, 2017, pp.55-56).

Art images have also given valuable insights into diseases and their social devastation, but they also reveal Indigenous etiologies. A drawing by a Nahua (Aztec) artist in the 1570s shows a tiçitl (female healer) surrounded by patients ravaged by smallpox - the pustules clearly visible on their bodies. Smallpox epidemics swept through Mexico in 1520 following the Spanish conquest, and this image from Book XII of the Florentine Codex graphically illustrates the suffering, but also the care given to victims during the first (of many) epidemics (Peterson \& Terraciano, 2019). In another example of Indigenous medical knowledge British colonials on arriving in the tropics of India and Bengal where smallpox was endemic, encountered the established practice of variolation ${ }^{2}$ in which a needle was dipped in the pus of smallpox sores and then applied as a prick to a healthy body - this medical procedure, which followed ritual protocol, was an early form of immunization and a precursor to vaccination.

Disease and the legacies of colonialism are as much the setting of Gabriel García Márquez's novel Love in the Time of Cholera (2003 [1985]) as is the fictionalised Colombian port city with its trade links along inland rivers and out to the Caribbean Sea. Here again disease, in this case cholera, is used in its multiple senses. Cólera refers to both the pandemic disease, but also to unbridled passion: love and rage. $\mathrm{Dr}$ Juvenal Urbino fights both the disease and unruly passion through his medical science and modernist agenda for order and progress. In the $19^{\text {th }}$ century cities around the

\footnotetext{
${ }^{1}$ Bloodlines is ostensibly set in Los Angeles, but strongly conjures up the Southern Gothic New Orleans genre.

${ }^{2}$ Named after the Variola virus that causes smallpox.
} 
world suffered from waves of cholera pandemic. Set in the late 1800s, the wealthy and aristocratic Dr Juvenal Urbina returns from his medical studies in Paris to launch a series of projects for sanitary reform in his native city. Cholera spreads primarily through inadequate treatment of human faeces and unclean drinking water, causing severe diarrhea, vomiting, dehydration and mass deaths. Colombia's long history of social stratification and wealth disparity (vestiges of colonial rule) are depicted in the city's racially divided District of the Viceroys and slums, its crumbling colonial architecture and sultry streets, and its sewer rats. While aristocratic families struggle to maintain their status, the cholera-afflicted poor of the slave quarters struggle for life. The final love scene of the novel equally rides the tides of disease. The two lovers, Fermina Daza and Florentino Ariza, are finally united in old age old and near the end of their lives. The captain raises the yellow cholera flag and the lovers - consumed by their plague of passion - set sail from the city on the quarantine boat.

In the graphic history book, The Great Hanoi Rat Hunt (Vann \& Clarke, 2018), narrative comic strips are used to tell the ironic case study of a rat hunt undertaken in the sewers of Hanoi under French rule of Indochina (Vietnam, Laos and Cambodia). The colonials had set about imposing modernist order on the city, creating a French Quarter of grand boulevards and villas, separate from the crowded Old Quarter of narrow crooked streets and buildings, which was left for the Vietnamese and Chinese. The urban renovation included installing sewers and water systems to prevent outbreaks of cholera. However, like the streets above, the sewers below were created according to racial segregation; the French Quarter with tap water and flushing toilets, the Old Quarter with community fountains and open drains. While Hanoi was undergoing this renovation the third bubonic plague had been creeping from one (port) city to another, and French scientists in the colonies were uncovering the link - rat fleas were the vector of the plague bacillus (Echenberg, 2007). When rats were reported in the French Quarter, alarm was raised. The sewers had provided the rats with both a haven for breeding and an efficient underground network with direct access to colonial villas. The authorities set out to hunt them down by promptly ordering Vietnamese labourers into the sewers. Thousands of rats per day were killed, but they kept coming. The authorities expanded the hunt, offering a bounty on each tail. The plan was thought successful as tails piled up, but then they discovered rats, now tail-less, freely scurrying about; they also uncovered a few industrious rat farms breeding the rodents for their profitable tails.

Tropical infectiousness is also the germ of scientific research that has lead to the design of heterotopia spaces such as lazarettos, plague ships, cordons sanitaires, hospitals, cemeteries and institutes of tropical medicine. Heterotopia is othered space, neither utopia nor dystopia, but worlds within worlds, simultaneously reflective yet disruptive of the outside. Heterotopia space is also implicit in colonial city design with 
its European quarters comprising hilltop panoramas, tree-shaded boulevards and sanitation systems, always removed from the low-lying insalubrious slums. Variations on this urban design were repeated throughout the colonial tropics - always racially and problematically associated with disease prevention (see Ngalamulume, 2021, this issue). Of course, the colony (with its port cities that draw large populations of people together, and its trade ships spreading goods, people, disease, rats and fleas) is itself an extreme form of heterotopia (Foucault, 1967) - the legacy of which continues long into the postcolonial era.

The rapid dissemination of the novel coronavirus disease around the globe, like diseases of old, relies on animal and human hosts, bustling cities, movements of people, and economies of trade. The new virus also calls up images of heterotopia spaces - plague ships, lazarettos, cordons sanitaires, hospitals, cemeteries, research laboratories.

\section{COVID-19: Origins Stories, Missing Links and Virus Hunters}

Although the story of the outbreak of the pandemic did not begin with the tropics - and thus punctuates the imaginary of the tropics as pestilential - the newly released joint report from the WHO investigation into the origins of the novel coronavirus SARSCoV-2 which leads to the disease COVID-19, does not erase the tropics as an origin site. In fact, the report recommends further investigations into links with the tropical regions of southern China and its connections with Southeast Asia.

The WHO report identifies the most likely origin story of the novel coronavirus is through intermediate zoonotic transmission. In this scenario the SARS-CoV-2 is transmitted from an animal reservoir (bats) to another animal host (spreading and evolving within that animal group) before crossing over to humans.

The closest related viruses to SARS-CoV-2 have been found in bats, however, there is still a substantial evolutionary distance between these bat viruses and the novel coronavirus. Thus the hunt is to find evidence of the evolution of a progenitor virus in an intermediate animal host population. As highly similar viruses to those in bats have been found in pangolins and the previous SARS-CoV virus (that caused the 20022004 SARS epidemic) was found in civets, the connection with wildlife species as host animals requires serious investigation (WHO, 2021, p. 115). This is a story of the quest to find the missing link.

Like previous SARS coronaviruses, the new strain of SARS-CoV-2 is a betacoronavirus ( $\beta-\mathrm{CoV}$ ) which is almost exclusively found in bats. The viruses most closely related to SARS-CoV-2 have been identified in the subspecies of horseshoe 
bats (Rhinolophus ssp.). Their genetic closeness to the novel coronavirus and their locations are significant for virus hunting (WHO, 2021, p. 83):

- RaTG13 is $96.2 \%$ similar. This sample was collected from bat droppings of the Intermediate horseshoe bat (Rhinolophus affinis) in Yunnan, southern China.

- RmYN02 is $93.3 \%$ similar. The sample was collected from bat guano of the Malayan horseshoe bat (Rhinolophus malayanus) in Yunnan, southern China. It also contains an insertion at the S1/S2 cleavage site in the spike protein (similar to SARS-CoV-2), indicating that such insertion events occur naturally.

- RshSTT200 and RshSTT182 are both 92.6\% similar. These two bat samples were collected from Shamel's horseshoe bats (Rhinolophus shameli) in Steung Treng, Cambodia.

- RacCS203 is $91.5 \%$ similar. Samples were collected from Acuminate horseshoe bats (Rhinolophus acuminatus) in Chachoengsao, Thailand. This sampling revealed near identical viruses found in five animals in the same colony, indicating a colony-specific virus signature which is evidence of recombination in the evolutionary history of this bat colony's coronaviruses.

These findings indicate that SARS-CoV-2 type viruses are found in multiple subspecies of the horseshoe bat which have a natural distribution across the Greater Mekong Subregion. The two closest bat viruses were from southern Yunnan near the Chinese border with Myanmar, Laos and Vietnam. One of these bat samples had a cleavage site in the spike protein, showing that this occurs in nature and bringing it closer in ability to bind to the human ACE2 receptor.

While genome sequence identity of the novel coronavirus has close similarity to bat SARS-related coronaviruses, there are also differences, and the challenge is to find the closest genetic match with SARS-CoV-2. Like previous SARS events, it remains highly likely that an intermediate animal host was involved. The hunt for this host animal remains ongoing. Malayan pangolins (Manis javanica) which were seized in anti-smuggling operations into southern China, showed viruses with $85.5 \%$ to $92.4 \%$ genome sequence similar to SARS-CoV-2 (WHO, 2021, p. 92). This is insufficient to prove pangolins are an intermediate host, but does demonstrate that pangolins have been infected in previous cross-species virus events. The virus hunt continues in wildlife animals known to be susceptible to coronavirus: pangolins, raccoon dogs, felines, mink and rabbits that can be infected by SARS-CoV-2, or species such as civets, ferret badgers and other mustelids, that were infected during the previous SARS epidemic of 2002-2004 (WHO, 2021, p. 93).

While the pandemic outbreak clearly began with the Wuhan wet market, and numerous samples from around the live animal section of the market tested positive for SARS-CoV-2, current evidence indicates that the virus may not have actually 
emerged in the market. Of the first 41 cases, 14 had no contact with the Wuhan market. This suggests that the virus was imported from elsewhere to the market, where it amplified. Thus the search for the origin of the virus includes tracing the distribution chains of wildlife animals and mapping their source sites onto sites of bat populations infected with viruses that match closely with SARS-CoV-2.

This mapping points to the subtropical Yunnan region of southern China for several overlapping reasons. The rural area - along with other rural parts of China - has undergone massive intensification in domesticated wildlife farming over the last two decades. The farms - from small family holdings to industrial complexes - breed animals that have been known to carry coronaviruses. This is also the site where virologists found the two closest known bat viruses genetically similar to SARS-CoV2. And recently the WHO investigative team found evidence that vendors at the Huanan Seafood Wholesale Market in Wuhan received domesticated wildlife supplies from these farms (Doucleff, 2021).

Wildlife domestication is part of a unique project that the Chinese government has been promoting as a key element in rural development, ecotourism and a way to bring rural populations out of poverty (Doucleff, 2021; Standaert, 2020). Rural populations in Yunnan include numerous ethnic groups, many of which share cultural practices and languages with Indigenous groups in neighbouring Myanmar, Laos and Vietnam. The development project was successful. It supplied wild meat (as well as fur products and animals for Traditional Chinese Medicine) bred in captivity rather than hunted from the wild; a 2017 report by the Chinese Academy of Engineering valued wildlife farm operations at $£ 57$ billion (Standaert, 2020); and in 2016, over 14 million people were employed (Doucleff, 2021). Then on February 24, 2020 the Government decreed a halt to farming of wildlife for food and closed down over 19,000 farms, including 2,300 in Yunnan (Standaert, 2020, Doucleff, 2021). The rapid closure of the farms indicates that the Chinese government assessed them to be a likely origin of the virus (Doucleff, 2021).

Nearly three quarters of emerging human infectious diseases have animal reservoirs, including both wildlife and domesticated animals (WHO, 2021, p. 92). Analysis of previous virus crossover events from animals-to-humans (zoonosis) show that they are facilitated under pressure of large-scale environmental and socioeconomic changes: climate change, deforestation, encroachment of human settlements, agricultural expansion and intensification, and trade in wildlife (WHO, 2021, p. 92; Sciortino, 2021, this issue). The cross over of viruses from animals to humans can occur through direct contact with infected animals, indirectly through animal products (cold chain meat products), or excreta, or via intermediate hosts (WHO, 2021, p. 93). Coronaviruses are known for their high recombination rate (the rearrangement of their 
genetic material) and are characterised by frequent host-shifting events: animal-toanimal; animal-to-human (zoonosis) and human-to-animal (reverse zoonosis).

The theory is that the virus moved from bat to farmed wildlife and then to human. However, in this scenario, no longer does wildlife conjure up the wilds of the jungle, animals have been domesticated to the large scale agroindustry. In such sites animals and humans are in close proximity and both are part of the the industrial machine laboring to produce meat: animals labour to produce their bodies as flesh; humans labour through the flesh of their bodies (Segata, et al., 2021, this issue). This relation between wild animal species and humans in the confines of the farm environment creates a closely entwined ecosystem which includes human and animal viruses. It creates a virulent zone (Fearnley, 2020).

Rather than an imaginary of jungle wildlife, we must re-imagine expansive landscapes of intensive domesticated wildlife farming - and their extensive networks of connections. "There is a large network of domesticated wild animal farms, supplying farmed wildlife" (WHO, 2021, p.115). And this landscape of high density farms, interconnected with each other via movements of labourers as well as transport networks supplying slaughterhouses and wet markets, generates infectious disease spaces - and opens up complex transmission pathways for viruses that are difficult to unravel (WHO, 2021, p.115). The hunt for the virus that will lead to the missing link and reveal the origin story of COVID-19 has only just begun. Two weeks after the WHO-convened investigation into the origins of SARS-CoV-2 report was released to the public, the World Health Organisation, along with World Organization for Animal Health and the United Nations Environment Program, called on countries to ban the sale of live wild mammals in markets. At the Geneva news briefing it was stated that the recommendation is not new, but COVID-19 has revealed the magnitude of the threat of zoonoses (VOA, 2021).

\section{Viral Sinophobia and Techno-Orientalism}

The viral image of a Chinese woman eating a bowl of bat soup and its connotation with both the Wuhan wet market and the outbreak of the novel coronavirus reduces the complex story of zoonosis processes involving animal-virus-human-environment to a simplified (and misleading) social media image based in Sinophobia.

"Ethnic scapegoating and xenophobic violence frequently erupt during disease outbreaks", Vann reminds us (2020). Epidemic xenophobia has a long history and has previously been linked with Chinese people across the colonised tropics and beyond. As Vann (2020) further argues, "during the age of high imperialism, Western medical experts linked Chinese bodies to contagious diseases such as the plague". COVID-19 
is not just medical, the virus is a poignant example of how "pandemics and Sinophobia are frequently intertwined" (Vann, 2020).

\section{"The Chinese Virus" \& "Kung Flu"}

In a series of tweets, the (now former) President of the United States, Trump, insisted on labelling the novel coronavirus "the Chinese virus", and when told to desist, instead tweeted "kung flu". Lok Siu and Clare Chun, record that this racialisation of the virus immediately lead to a huge rise in hate crimes against people of East Asian and Southeast Asian descent (Siu \& Chun, 2020, p.421). In America over a thousand incidents were recorded within the two-week period following the tweets, including an America Asian woman attacked with acid, and a Burmese American man and his two children stabbed in the belief that they were "Chinese and infecting people with coronavirus" (Siu \& Chun, 2020, p.422). The viral hashtag \#chinesevirus infected populations around the world. In the UK a Singaporean student was brutally attacked by a group of men stating, "we don't want your coronavirus in our country" (Siu \& Chun, 2020, p. 422). In Australia, the tabloids Herald Sun and Daily Telegraph inscribed on their front pages "Chinese Virus Pandamonium". In France, the Courrier Picard featured the headlines "Yellow alert" and "New yellow peril?" Asian-French citizens, with ancestry primarily from the former French colonies of Indochina (Vietnam, Laos and Cambodia) responded to race hate through a peaceful protest campaign employing photographs of themselves holding up signs reading "Je ne suis pas un virus" [I am not a virus]. Posted on social media, this pun on the famous painting Ceci n'est pas une pipe by René Magritte, likewise went viral.

The racialised imagery of Chinese as having 'strange' eating habits, wet markets as disease-ridden spaces that traffic in the flesh of wild animals, and Wuhan as the epicentre of the outbreak, became entrenched in the media. The zoonotic emergence of the novel coronavirus had been reduced to clichés, China vilified, and Chineselooking people victimised. Then President Trump postulated (tweeted by the then Secretary of State Mike Pompeo on April 30, 2020), that "COVID had originated in the Wuhan Institute of Virology, which houses a biosafety level-4 lab, and that the virus might have "leaked" from that lab" (Siu \& Chun, 2020, p.422). The implication was that China had either accidentally leaked the virus and therefore could be accused of scientific negligence and denounced as incompetent, or the state had bioengineered the virus for the purposes of mass destruction and therefore can be accused of global malice (Siu \& Chun, 2020, p.422). Despite immediate refutation from leading scientists and a statement from the Office of the Director of National Intelligence that the "COVID-19 virus was not manmade or genetically modified" (Siu \& Chun, 2020, p.422), the fact that the unsubstantiated speculation still weighs heavily on any scientific investigation into the origins of the SARS-CoV-2 virus a year later, 
demonstrates that these racial tropes are strongly implanted in the popular imagination - from colonial imaginaries of the Chinese as diseased, to futuristic dystopian imaginaries of China as a techo-menace.

Sinophobia and racial violence had been released - along with the implanted notion that China was responsible for unleashing the pandemic on the world. As Gregory Lee notes, Trump's tweets and the hashtag \#chinesevirus "ethnicized, and indeed weaponized, COVID-19 as the "Chinese virus"' (Lee, 2021).

\section{Yellow Peril \& Dr Fu Manchu}

It is important to remember that racial slurs like "the Chinese Virus" and "kung flu" did not simply arise within the current pandemic. "Such terms have been used over a long period to stoke fear of contagion, contamination, and sickness portrayed as arising from a unique difference in lifestyle and daily practices, especially cooking and eating habits" (Lee, 2021). In the current pandemic the "Chinese as contagion" trope has been (re)invoked, calling upon historical notions of "Chinese as diseased bodies and pathogenic carriers" (Siu \& Chun, 2020, p.427). Indeed, the racialised terms act to naturalise the "virus as being endemic to Chinese bodies, thereby conjuring the phantasm of the Chinese/Asian contagion" (Siu \& Chun, 2020, p.428). And they do this by calling on the trope of the "yellow peril". As Gregory Lee observes, "Chinese diasporic communities around the globe have been consistently perceived as particularly invasive and infectious, as carriers of the contagion of Yellow Peril" (Lee, 2021).

The manifestation of the notion of a "yellow peril" first arose during Western imperialist expansion in East Asia. The term quickly evolved to attach itself to any, or all, Asian peoples who were seen as an economic, technological or industrial threat to Western geopolitical dominance. The term is particularly viral and "the notion of the nondifferentiable "yellow" masses continues to function as a homogenising and dehumanizing device of Asian racialization, which makes possible the transference of Sinophobia to Asian xenophobia" (Siu \& Chun, 2020, p.425).

"Yellow peril" is a projection of the Western fear of the Asian other - whether of East Asia or tropical Southeast Asia. Gina Marchetti (1993) traces the "yellow peril" psychocultural fear of Asians back to Genghis Khan and the Mongol invasions into Europe. The term is used to "animate a myriad of representational figures, images and discourses" which shift and change to suit various contexts, and is called upon to represent the perceived multifarious threats of Asian peoples (Sui \&Chun, 2020, p.425). These threats have been conceived as: biological (disease carriers and inherent effeminacy); military (promulgating in the incarceration of Japanese- 
Americans during WWII); economic (the vilification of Chinese labourers in the late $19^{\text {th }}$ century and the Japanese in the 1980s); and moral depravity (heathens, Chinese prostitutes, opium smokers - or consumers of bat soup and exotic wildlife) (Siu \& Chun, 2020, p.425).

The current iteration of "yellow peril" displays anxieties regarding the contemporary moment and China's rapid global economic growth, its massive population with rising consumer and travel power, and the country's formidable techno-scientific advance. It is furthermore being reconfigured through a techno-Orientalist imaginary where China's scientific, technological and economic power is posited as the number one enemy-threat challenging the position of America's geopolitical dominance (Siu \& Chun, 2020, p.424).

The notion of the "yellow peril" is most prominently embodied in Dr Fu Manchu. From his incarnation in 1913 as a character in what would become a series of popular novels, Fu Manchu has featured extensively in cinema, television, radio, comic strips - including for the French newspaper Le Parisien Libéré - a comic book and pop music. Dr Fu Manchu became the Chinese archetype of the evil genius and mad scientist.

Created by the English novelist Sax Rohmer, the sinister Asian mastermind persistently plotted the destruction of the Western world. His murderous plans are themselves conspicuously racialised. Dr Fu Manchu has a penchant for esoteric methods, rejecting the use modern guns or explosive devices, he prefers to employ knife wielding dacoits from Burma and Chinese secret society agents, he utilises pythons, cobras, tarantula and other exotic tropical animals, weaponises natural chemicals such as fungi or bacilli, and dispatches his enemies through torture - human sacrifice, lowering the victim into a crocodile pit, placing them between plates of metal spikes inching towards each other; or enslaves them through injecting a serum that renders them into zombie-like obedience. The machinations of $\mathrm{Dr} \mathrm{Fu}$ Manchu embedded "lurid clichés" in the public mind and his characterisation propelled a "reentrenchment of the perception of "Chinese" people and things as an evil foreign menace" (Lee, 2021).

Dr Fu Manchu's Eastern mysticism blended with Western science, makes him one of the earliest and most potent expressions of techno-Orientalism (Roh et al., 2015). As David Roh, Betsy Huang and Greta Niu observe, the monstrous and brilliant Dr Fu Manchu "captured Western ambivalences toward what it regarded as the mysterious power of the East, manifesting in strange contradictions" (2015, p.1). 
In one part of the serial, Dr. Fu Manchu plots to strengthen China by kidnapping European engineers, suggesting the Orient's lack of technological prowess and desire for Western technology. Yet, in another, he is described as possessing "all the cruel cunning of the entire Eastern race, accumulated in one giant intellect, with all the resources of science, past and present." (Roh et al., 2015, p.1)

In the American film adaption of The Mask of Fu Manchu (1932), the doctor is portrayed with exoticised and orientalised 'Chinese' markings. Extending Abigail De Kosnik's (2015) description, he wears brocade silk robes, has long fingernails, upward slanting eyebrows, and a tapering downward-curving moustache - which has since been named the "Fu Manchu". His cavernous lair is decorated with Asian art and artefacts, and extends into a laboratory complete with state of the art scientific and medical equipment. Although in the novels Fu Manchu says he attended Heidelberg University, the Sorbonne and the University of Edinburgh (Emperor Fu Manchu, 1959), in the film he expounds he has a doctor of philosophy from Edinburgh, a doctor of law from Christ's College and a doctor of medicine from Harvard.

In the film, Dr Fu Manchu plans to steal the gold scimitar and mask excavated from the grave of Genghis Khan by an archaeological team for the British Museum. Believing in the mystical power of the artefacts, he intends to proclaim himself the reincarnation of the fearsome conqueror and to bring together the peoples of pan-Asia to usurp the "white race". Invoking well-worn "yellow peril" images including, Asian hordes (rendered as faceless, mass produced, standardised, but always stamped 'Asian'), as well as "scenes of oriental depravity and cunning", the film upholds notions of white supremacy and "spins a sinophobic tale about the illicit quest for global expansion in defiance of the British Empire's own expansive thrust" (Mayer, 2012, p. 402). As Ruth Mayer observes, when Fu Manchu as orientalised scientist-engineer tests the authenticity of the scimitar through the electric-sparking Tesla coil "the distinction between science and cult is suspended, with Fu Manchu in his ornate robes, in his sophisticated laboratory, figuring as the ultimate scientist-magician" (Mayer, 2012, p.406).

\section{Techno-Orientalism and Pandemic}

Techno-orientalism brings traditional orientalist imaginaries into the modern technological environment. As with Orientalism of previous centuries it is a way for the Occident to retain a sense of power in a rapidly changing and inherently interconnected world. It combines iconic imagery of an exotic Asia with futuristic, science-fictionesque imagery. Reading Dr Fu Manchu as the incarnation of "yellow peril" within an early techno-Orientalist projection allows us to see the deeply 
implanted and relentlessly recurring images of Sinophobia and Asian xenophobia that are re-animated in the current context of the COVID-19 pandemic. The rise in racism certainly has its vectors in viral hashtags, but these are further entwined with previous epidemic tropes of "yellow peril", unmasked in cinematic depictions of Fu Manchu, and entangled with the geopolitical fears of China's rapidly growing economic, technological, and scientific capabilities.

In the contemporary context, Chinese and Asian racial difference is being re-animated in the intertwined arenas of pandemic, economics, cybertechnology and science. There is a plethora of global media coverage concerning accusations and actions launched against China, as well as people of Chinese or Asian descent living in a multitude of countries around the world. There has been the implementation of trade sanctions and tariffs against China, the removal of prominent Chinese American scientists from research institutions, and the severing of nationwide economic transactions with some China-based telecommunications corporations. (Siu \& Chun, 2020). The tropes of the Chinese-Asian body as diseased, China as a biosecurity threat, the cyber-engineer as thief and the Chinese scientist as spy, continue to circulate in pandemic waves of social media catchword hashtags.

\section{Pandemic, Plague and Pestilential Imaginaries}

Pandemics, plagues and pestilence are not just epidemiological events, they are also social, and infect the social imaginary. The very terms pandemic, plague and pestilence are intertwined, often standing in for each other. Pandemic refers to a global epidemic; plague likewise connotes a disease of deathly geographic reach, but also specifically refers to the bubonic or pneumonic plague; pestilence, too, refers to a highly contagious epidemic disease of vast proportions, but may also refer to the plague (from its root in peste - plague), and additionally connotes a sense of noxious and pernicious morality, a malignity - such as Sinophobia - that can infect great numbers of people. These terms draw together various clusters of images. Pandemic is a terrifying myth of the world being swamped by disease as much as it is an epidemiological term to measure the geographical extent of an epidemic outbreak of disease. Likewise, various epidemic diseases create specific, yet overlapping imaginaries and associations. Plague draws together images of climate, rats, fleas and genetics (Eisenberg \& Mordechai, 2020); cholera is associated with water, faeces and sewers; yellow fever with swamps and mosquitos. All involve humans, our flesh and our scientific and social imaginaries. Such imaginaries also involve geography. Our emphasis is on the Tropics. More than just a geographic band around the Equatorial centre extending outwards to the latitudes of the Tropics of Cancer and Capricorn and with climate change spreading further north and south - the tropics has been the site of a pernicious imaginary as a zone of pestilence. 
This Special Issue has been created during a time of pandemic and involved an editorial team whose expertise across the arts, humanities and social sciences, concentrates on various parts of the tropical world, including Asia, Oceania, Latin America and Africa, with the central editorial coordination coming from the small island of Bali. Like authors and readers, the editors' various locations of research have been affected by the novel coronavirus pandemic, which itself has been influenced by historic pandemics and their imaginings. Here the editors each offer a short reflection on pandemic experiences - present and past. Thus we turn briefly to the island of Bali, to Asia, Oceania, the Americas and Africa, in order to offer a 'situational interlude', before outlining the collection of papers brought together in this issue which spread their investigative tendrils more widely across the tropical regions of the world.

\section{Plague Masks - Bali}

As Bali closed its borders to international travel (and strongly restricted domestic travel from other parts of Indonesia), many tourists, digital nomads and social influencers chose to stay on the much lauded "tropical island paradise" to wait out the pandemonium (the pan-demon of Milton's Paradise Lost). While Balinese, and a majority of expats, followed the Governor's various ordinances regarding semilockdown, self-quarantine, cordons sanitaires (including beaches), social distancing, hand washing and a mandate on mask-wearing, many tourists flouted the health protocols.

The most conspicuous site of rebellion became the face - and the artefact of the mask (see also Ferrão, 2021, this issue; Witkowski et al., 2021, this issue). The mask signified a difference in attitudes between the Balinese and the 'bule' (meaning foreigners, 'whites', Europeans) tourists. At first the Balinese tried to educate tourists about the need to wear a face mask, until it became obvious that bule were choosing to break the law. The pecalang (traditional village security guards) offered free masks at road blocks, the police put up signs in English and Russian with illustrations on how to wear a mask, later small fines were introduced (the same penalty for Balinese and bule transgressors), law breakers were made to do push ups (embarrassing for Balinese, amusing to tourists), and finally heavier fines ( $R p 1$ million, about SG\$100.00) were introduced for tourists, with deportation for second offenders (as of 9 April, 2021, over 300 foreigners were fined and six deported).

Balinese and numerous expats were perturbed as to why many tourists refused to wear face masks whilst guests on the island. More than Western individualism verses Balinese communalism; or sociopathic verses empathic behaviour, as psychological 
analyses have theorised; or conspiracy verses science - this drama relates to the theatre of tropicality and the artefact of the mask.

In the island setting, non-compliance became a type of exceptionalism, a form of neocolonialism tied to tropicality. The temperate peoples having entered the tropics and and chosen to be marooned on an island-heterotopia, retained an imagined immunity qua a temperate zone of protection, which detached them from the susceptibility of life and death of Balinese people around them. The uncovered face became a display of invincibility and Western superiority. Tourism as a rampant form of neocolonial exploitation was unmasked (see, Clayton, 2021, this issue).

Masks (and not wearing masks) have power. Thus Dr Fu Manchu's belief that the mask of Genghis Khan could transform him into the leader of pan-Asia in a revolt against the powers of the Western world. However, it is not the golden mask, but rather a plain white surgical mask that is particularly iconic. In a scene in the film, Dr Fu Manchu is in his modern laboratory: a tarantula and large python are removed from domed medivac containers, their animal venoms extracted using a syringe (in the case of the python after it has been forced to bite one of Dr Fu's attendants), and the concoction is mixed in a flask over a Bunson burner (Brabin, 1932). Yet what stands out in this exotic science scene is the doctor's medical attire. Dressed entirely in white, he wears a long surgical gown, scrub cap and a mask.

The image resonates with photographs of Chinese doctors during the Manchurian plague epidemic of 1910-1911. Medical teams from China, Japan, Russia, America and Europe arrived on site. The lead doctor for the Chinese team was Wu Lien-teh (Wu Liande), who was actually from British Malaya and had studied at Cambridge University. As the medical anthropologist Christos Lynteris extensively documents in his paper Plague Masks (2018), Dr Wu Lien-teh reasoned that unlike the bubonic plague, which is spread from rats to humans via flea vectors; this was airborne and spread directly from person to person. The plague caused pneumonia and within 2448 hours of showing symptoms would kill everyone it infected. Dr Wu set about adapting surgeons' masks into cheap and easy-to-wear anti-plague masks. The masks were to be worn by doctors, nurses and sanitary staff, as well as patients and their contacts, and distributed among the population of the affected region. The Japanese and European doctors remained sceptical and one eminent French doctor, an outspoken opponent of $\mathrm{Wu}$, refused to wear a mask. He contracted the disease and died; the masks were quickly adopted by all the doctors and among the public. By the time the plague abated in April 1911, approximately 60,000 people had died. The masks were believed to have prevented an even greater catastrophe (Lynteris, 2018). 
As has been extensively studied by anthropologists, masks are not just to conceal or to protect (from magic or germs); they are transformative - as we know from their use by superheroes, and also by Balinese dancers (see Lundberg, 2020; Lundberg et al. 2019, p. 5). Likewise, Dr Wu's medical masks were transformative: displaying China as a modern and scientific nation, disrupting colonial power relations, and metamorphosing the image of Chinese people from 'a superstitious and ignorant' horde, into an 'enlightened and hygienic-minded population, a population that accepted the contagious nature of the disease' (Lynteris 2018, p.451). Dr Wu Lien-teh made sure the anti-plague operations, and his masks, were extensively photographed. From January to March 1911, the photographs were featured in newspapers around the world. The anti-plague mask went viral, and masks were quickly adopted during the 1918 Spanish Flu pandemic (Lynteris, 2018).

In Bali, the mask situation continues to escalate. Government authorities, heads of banjars (subvillages) and a growing number distraught expats, were at a loss as to how to confront the (ob)noxious refusals to wear masks. Then, suddenly, action came in the form of art activism - large scale billboards started appearing around Ubud.

John Logan, an expat living in Ubud, is best known for his black and white photographs of ordinary Balinese people - labouring in rice fields, gardening in jungle plots, selling produce in the markets. He is also a street photographer, snapping fast shots of tourists in their everyday pedestrian lives. Logan's most famous photographs have a particularly striking quality which creates hyper-reality out of the mundane and quotidian. These photographs are often portraits of elderly Balinese as full body shots or close ups of hands and faces. His high-definition, high-contrast images with sharp tonal gradations shot under the strong tropical sun, expose patterns, textures and lines - of muscled bodies that have laboured all their lives, of ravaged faces that have a glint in their eye.

The billboards feature a large black and white photograph of a thin, highly muscular, farmer - bare chested, tattered shorts, arms held outwards with parang (machete) in hand. He looks straight at the camera; sternly, face mask on. He stands in his rice field filled with rough mud and the knobs of ploughed-in rice plants. This is defiance and renewal. At the top of the image is the title "Bali Unbalanced", with lettering within black and white checks and the entire image framed within a border of red, white and black. This is significant: the black and white checks are saput poleng, a cloth which is seen everywhere in Bali - draped around statues and sacred banyan trees, or held aloft in shrine and temple umbrellas. It symbolises Rwa Bhineda, the balancing of harmony, and further sekala and niskala, the visible and invisible worlds. The red, white and black border is Tridatu, the three powers, and embodies the Trimurti, the three manifestations of the gods. Red is Brahma the Creator, white is Siwa the Destroyer, 
and black for Wisnu the Preserver - the Bali-Hindu cycle of birth, life and death (Eiseman, 1990). Surrounding the central black and white image, but outside the protection of its tri-coloured frame, are 84 colour photographs; street snapshots of tourists as they go about their day on foot, bicycle or scooter - mask-less. One of these photographs is different, it is of a bull patulangan (casket) burning in flames. This is ngaben, the cremation ceremony which releases the soul of a dead person so it can enter the upper realm to wait to be reborn, or to be liberated from the cycles rebirth.

Figure 1. Bali Unbalanced

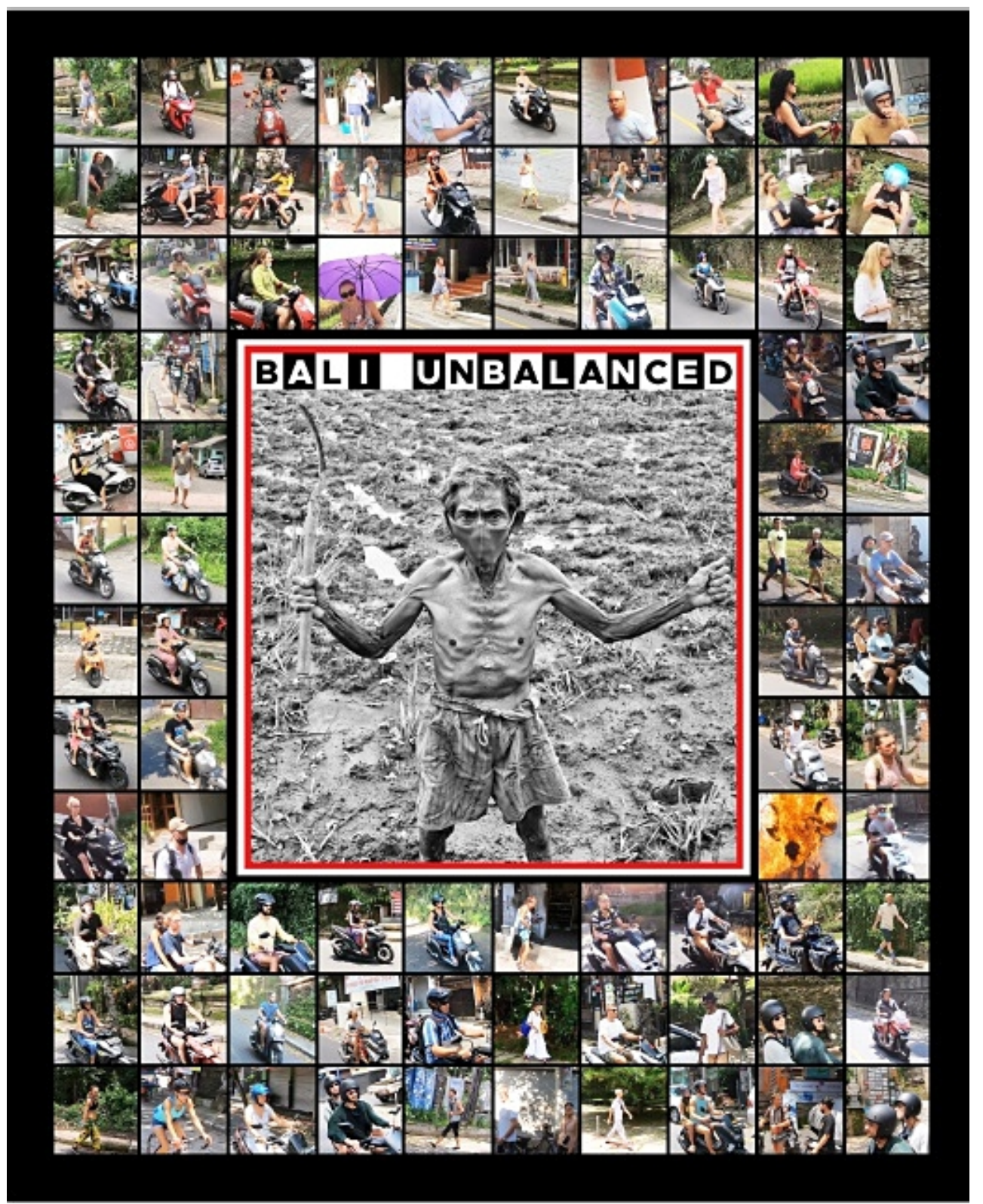

Source: John Logan, 2021. Photographs, printed on billboard. 2.5 × 2.0 metres. 
The billboards have caused a significant local sensation. The project started as just four billboards at the main gates (the symbolic North, South, East, West) of Ubud's central market. ${ }^{3}$ From this central node, Logan hoped the message of the billboards would radiate outwards on the local trade and gossip networks to surrounding banjars and villages. However, there was a moment of concern regarding just what that message was: the morning after the billboards were erected, a local seller asked the chief administrator of the market "so do we not have to wear masks anymore, like them" pointing at the photos of the tourists. Logan was asked to put an explanatory plaque below the billboard. He was also asked by village heads to make billboards that could be erected in their banjars. The billboards have not been without controversy. Immigration visited one of the villages explaining that there had been complaints from tourists. The village head responded that the billboards were voicing what the Balinese were thinking. This was followed by a meeting of the divisions of Immigration, Police and Tourism; the billboards were to stay. There are now 18 around Ubud, all have been gifted to the banjars. Facebook has been alive with messages from bule - either in support, or accusing the photographer of being in violation of privacy and a stalker. ${ }^{4}$ One of the billboards was vandalised by a Westerner, who selfproclaimed his act on Facebook, only to be informed that he had defaced banjar property - he blocked the village head who tried to contact him regarding the crime (Logan, 2021).

What Logan has done, which is so unsettling, is to move the camera lens from the Balinese as exoticised subjects of the Western imagination, and instead put the focus on tourists - and in the process unmask them. Logan has a sardonic sense of humour, he calls the mask-less tourists he captures in photographs his "models/influencers", a direct comment on the influx of social media influencers into Bali who continue to Orientalise local people, customs, and the tropical landscape for their own consumption (Lundberg, 2020, p.96).

\section{Pandemic Literatures - Asia}

In literature, the social pandemic is often portrayed as more impactful than the epidemiological event. This reciprocal relation between scientific-medical and sociocultural aspects of epidemics calls for them to be understood together. Both live on deep in human memory. This is particularly the case with Indigenous mythologies and ritual performances which are literary repositories that describe and re-enact human

\footnotetext{
3 The billboards were proposed and went through the usual administrative sections in order to be granted permission: Ubud Market Organisational Committee, Ubud Kecamatan (district), Gianyar Kabupatan (regency), Denpasar (capital of Bali), Jakarta (capital of Indonesia).

4 The photographer doesn't actually stalk (in the sinister implication of the term). The project arose out of documenting the streets of Ubud as the pandemic took effect and shop after shop started closing down (this has been a yearlong project). Logan rides around Ubud with a GoPro camera strapped to his head. The camera captured more and more bule mask-less, and was in part instrumental in igniting the the billboard art (Logan, 2021).
} 
crises experienced in the wake of invasion and the ensuring epidemics of disease (see Duin, 2021, this issue). The spectre of epidemics is also a persistent underlying motif in the literature of later colonial peoples writing of social changes towards the ends of empire (see Priyanka, 2021, this issue).

In times of pandemic people call on literary expression - whether in the form of novels, theatre or film - in order to understand the event. Thus, the novel coronavirus has spurred an epidemic rise in the reading of pandemic literature. Imaginative works from the tropics include the aforementioned classic, Love in the Time of Cholera by Gabriel García Márquez, set in historic Colombia in the Americas. The Transmigration of Bodies (2016 [2013]) by Yuri Herrera, a post-apocalyptic noir fiction set in an unidentified corrupt Mexican city ransacked by plague, follows a fixer trying to arrange the exchange of bodies between rival gangs. The novella Beauty Salon (2009 [1994]) by Peruvian-Mexican writer Mario Bellatin, takes place in a beauty parlour turned into a shelter for men to spend their dying days as their bodies lie ravaged by an undefined plague that scourges the unnamed city. The speculative fiction debut novel The Book of M (2018) by Peng Shepherd, is set in India in a perilous near-future world during a plague of disappearing shadows, and with them, the loss of all memories. The Old Drift (2019) by Namwali Serpell, begins on the banks of the Zambia River, Africa. An old fever-riven drifter makes a mistake that entangles the lives of three Zambian families from different racial-ethnic backgrounds, and between historical fiction, sci-fi and magical realism, the story weaves in technological marvels like Afronauts, microdrones and viral vaccines.

Times of pandemic quarantine have simultaneously created the space from which great works have emerged. The $16^{\text {th }}$ and $17^{\text {th }}$ century plague outbreaks are reflected in William Shakespeare's dramas. In the midst of a potently creative period, Shakespeare, at times in quarantine, produced Romeo and Juliet, Macbeth, King Lear, Antony and Cleopatra, The Tempest, and Coriolanus - a tragedy alluding to contagion and plague. His works, however, rather than being about epidemics, were imbued with plague atmospherics, as is the case with Romeo and Juliet; and likewise the plague would arise as expletives, bringing perspective to the famous line: 'A plague o' both your houses!". In Macbeth plague imagery is strongly evoked, however, this is not a medical illness, but refers to the plague of a viscous and ruthless leader. As Stephen Greenblatt (2020) summarises:

In office, Macbeth has ruthlessly pursued his enemies and betrayed his friends. Egged on by his "fiend-like" wife, he will do anything to make himself feel perfectly secure - "Whole as the marble, founded as the rock." But, though he always finds people willing to carry out his criminal orders, he only ever feels more anxious: "cabined, 
cribbed, confined, bound in / To saucy doubts and fears." And, under increasing pressure, calculation gives way to raw impulse, the reckless confidence that his instincts are always right: "From this moment / The very firstlings of my heart shall be / The firstlings of my hand."

In Macbeth, we are warned, "Physic himself must fade" (Greenblatt, 2020). Reminding us that a solution to plague is not medical alone but always, also, entwined with the the socio-politico-economic (see also Ghosal, 2021, this issue).

Pandemic quarantine, however, cannot automatically be assumed as a space of creative production - in contemporary times, the imposition of of self isolation, combined with the persistent infiltration of an overload of social media information, morphing statistics and conspiracy, has equally created an involuntary vacuum in the contemporary literary world. As the pandemic raged with waves of fatalities globally, literary works from Asia, particularly Southeast Asia have often taken a back seat as writers closely observe, and patiently search for a small window of illumination (see Benitez, 2021, this issue). However, two works worth mentioning involve themes revolving mostly on lockdown effects and reflections. One is a collection of poetry, short stories, and art works, titled Unmasked: Reflection on Virus-Time (2020) curated by Singapore-based Malaysian author, Shamini Flint; the other is an anthology of short stories, The Lockdown Chronicles (2021), edited by Shireen Zainudin and Viji Krishnamoorthy. The earlier work includes varied background settings and contributions ranging across Singapore and Malaysia to Australia and further, while Chronicles' stories are mostly set in Malaysia. These two anthologies, collectively, reveal that writers are on hiatus, their reflections staying within the imposed imprisonment rather than questioning the viciousness of the virus itself as a biological or social event - thus offering some sort reprieve from our daily chaotic lives, a salve rather than a stimulant inspiring social analysis. However, a more critical reflection on the pandemic that questions the experience and the social-politic life of the virus emerges in Christian Jil Benitez' poem which interrogates the everyday debilitating empty-time of lockdown in a Philippines replete with political and ecological nuances (2021, this issue). In another vein, a speculative flash fiction piece, Christina Yin offers a post-pandemic dystopian view into the far future on a cold outer planet of the solar system where citizens desire eco-tropical holidays to a future utopian island of Borneo (2021, this issue).

Film scripts often use pandemics to dramatic effect. And, as with novels, these pandemics are revealed as human, biological and social events. The recent South Korean zombie-induced films Peninsula, directed by Yeon Sang-ho (2020) (a 'nonsequel' to 2016 Train to Busan), and the parasitic aftermath drama \#Alive, directed by 
Cho II-hyung (2020), portray East Asia as the hub of infectious diseases and contagious pestilence, reflective of the origin story of the SARS-CoV-2 virus as arising unproblematically from the East Asian region. As such, the films, as creative productions, remind us of the now well-known epidemiological investigations that have for decades indicated Asia as a virulent site for pandemic, with the films visualising this fear. Nevertheless, these films lack the critical interrogation that pandemics as imaginaries deserve. The role of zombie film is more deeply interrogated in Milan Kroulik's work in which he links the tropics as imagined zones of disease with notions of the zombie and questions regarding the autonomy of the human body (2021, this issue).

\section{Epidemic Cultural History - Oceania}

In his Hot Countries: A Travel Book (1930), Alec Waugh takes his readers on a series of journeys into the Caribbean, South Asia, Southeast Asia, and Oceania of late colonialism. At the end of the historical semi-autobiographical novel Waugh reflects on the destruction of Tahiti by European presence when he notes that the island and its inhabitants have been betrayed by "the fatal gift of beauty". Beauty has been fatal to the tropical imaginary because it has provided a draw card for European presence and the subsequent epidemics of disease that have destroyed indigenous cultural heritage and homelands across the expanse of the Pacific Ocean from Hawai'i through the islands archipelagos to the tropical east coast of Australia. Furthermore, implies Waugh, 'the fatal gift" has also proved lethal for Europeans who want to experience their imagined tropics only to succumb to indolence, alcoholism, and illness (see also Saunders, 2021, this issue). Waugh's observation demonstrates the complexity of the tropical imaginary: while it can be a place of beauty, imagination, uniqueness, and wonder, the tropics has also been historically perceived as a place of pestilence, plague, and pandemic danger.

Our present perception of the tropic imaginary is an accumulation of all that has been imagined before. When we imagine 'the tropics', we are perceiving more than landscape: in our search for a meaning of tropicality we are envisioning our encounter with a cumulative place that is both imaginary and literal. That is to say, although we might be standing in the physical, geographic Tropics, we are inevitably comparing it to our imagined tropic that has been developed in our mind from all that we have previously read and seen. Yet, despite all the accumulated literary, filmic, documented and scientific resources about the tropics, this zone has persisted in being conjured as a dangerous, pestilential place of the unknown, into which we venture at peril (see Clayton, 2021, this issue). The jungled darkness of the tropic imaginary, into or over which the Westerner could not see and thus dominate, has prompted fear not only of what might be within that dark interior but also of what might be revealed within those 
who venture within. The jungle of the tropic imaginary reflects nothing back, allows no vison forward; those who enter are forced to look within themselves, at their own peril.

In reality, however, a very large part of the tropical world is not landscape but marinescape: the tropics are complexly maritime, and were experienced by voyaging within an elemental space of sea, weather, and sky. In comparison to the land-based tropical experience, the maritime experience is one of vison as the voyager looks out across the expanse of ocean in anticipation of encountering the new and different, both a physical and metaphysical experience, each shaping the other in the context of an ongoing, extended encounter between being, space and place. Western colonial writers of the Pacific such as Melville, Stevenson, Becke, London, and O'Brien ensured that the Pacific tropical imaginary remained both an ocean and an island encounter in which the difference of tropical place and person registered on the Western body as much as on the Western mind (Spicer, 2021, this issue). As such, they were intent on bringing together marine-scape, landscape, and people into the tropical imaginary of the 'sea of islands,' while also drawing attention to the manner in which this imaginary was changing due to the impact of the Western world on it. This was an archipelagic consciousness (Carter, 2013).

Those Anglo-Europeans who travelled to experience the tropics were immediately aware of the contrast between their former place and this tropical one, and that contrast between the temperate and the tropic is one of the most enduring themes in the history of global imaginings (Clayton, 2021, this issue). This contrast is also rendered in differences experienced within continents that bridge the tropical and temperate zones. On the edge of Oceania on the vast island of Australia, the tropical 'top end' is experienced as other to the temperate south. Far North Queensland on the edge of the Pacific, for example, has historically regarded itself as so meteorologically, biologically, topographically, and demographically different from the Southern part of the state that it has persistently raised the issue of succession.

Whether represented positively, as in fantasies of the tropical sublime, or negatively as a pathological space of degeneration, tropicality has frequently served as a foil to temperate Nature, as well as the nature of humankind. The tropics have long been the site for Anglo-European fantasies of self-realisation, projects of cultural imperialism, or the politics of human or environmental salvage, and within literatures of natural history, travel, exploration, and fiction, the idea of tropical difference has had a remarkably sustained and persistent influence on how the tropics are perceived. Yet while the tropical imaginary may have suffered from that 'fatal gift' the tropics remains a growing presence - literally and imaginatively. 


\section{Pestilential Ecologies - South America}

Literature, History, and Social and Health Sciences often portray the tropics as a challenge to civilisation. Pandemics, plagues, pestilence, and also a hostile nature, needed to be tamed - which is why they always appear at the center of narratives that combine failures and triumphs. Many images characterise this scenario, but Urupês, by Monteiro Lobato (2019 [1918]), may offer a unique expression of this imaginary. Centered on the character Jeca Tatu - a yellowish, weak, uneducated, worm-ridden man - the widely-read author of Brazilian fiction described the country at the turn of the 20th century as "a great hospital" (Lima \& Hochman, 2004). ${ }^{5}$ On one hand, time after time, syphilis, smallpox, plague, and yellow fever raged through the Brazilian capital. On the other, the sertão - a space that in Lobato's description synthesised everything that started at the end of Rio de Janeiro's central avenue - was a colossal breeding ground of an endless number of parasites, hosts, and vectors that, mixed with the dirt and laziness of the many Jeca Tatu types, established disorder and impeded the progress of the nation:

In the debate about national identity, it is common to see man's fragility in the face of tropical nature. This contrast and the idea of inadequacy between the natural environment, man, and European culture are constant themes in Brazilian social thought.... The hinterland appears as a problematic nature to domesticate... as a synonym for disease and a hostile nature to man. (Lima \& Hochman, 2004, p. 502-503)

In response, the Brazilian authorities broadly stimulated an overall eugenic-neocolonial whitening process during that historic period. Italian or German men - the new European colonizers - were imagined as the material opposite of Jeca Tatu. They were the symbol of education, vigor, virility, and the capacity for development. It would be up to them to pioneer the interiors of these lands of opportunity, which needed to be cultivated with an eye towards the future. However, the problem was that on descending from their ships, these men succumbed to tropical diseases. Efforts needed to be instigated and intensified around a science aimed at acclimating white men to "warm lands" - a Tropical Medicine (Lövy, 2006).

Among the many practical guidelines offered by this new discipline was the idea that it would be necessary for white men to mingle with the local population to strengthen their descendants. Crossing their European bodies with those naturally immune to local diseases was highlighted, especially in the case of yellow fever disease (Löwy,

\footnotetext{
${ }^{5}$ The book, selecting tales and chronicles, was initially published in 1918, inaugurating a more critical regionalism in Brazilian literature than previously practiced in its romanticism period. See, Lobato, (2019).
} 
2006). Also, several research missions had made the tropics an exciting open-air laboratory, expanding and consolidating other nascent modern sciences such as microbiology and international health. As noted by Lima and Hochman, "science would represent an alternative to this profusion of uncomfortable forms of life, an artificial defense in the face of the failure of the natural defense of men weakened by the civilizing process" (2004, p.505).

The Institution of Tropical Medicine in São Paulo, the mission of the Pasteur Institute in Rio de Janeiro, the research and actions of Oswaldo Cruz, and the work of the Rockefeller Foundation along coastal areas would mark a new phase of political, scientific and urban changes in Brazil. This shift in the forms of research and control - mainly related to hookworm (the disease of the character Jeca Tatu) and yellow fever - was associated with identifying the worm and the discovery of the Aedes aegypti mosquito. More than pathological agents and vectors, these anthropic beings, morally linked to poor people, materialised what we can call the "infrastructures of intellectual colonization". To paraphrase the idea of Mary Louise Pratt (1992), this refers to a kind of anti-conquest in the world of health with regards to the way naturalists explored their European representation of nature around the world by naming and classifying species of plants and animals, without conceiving of local biologies and indigenous modes of understanding them. Worms and mosquitoes make the presence of the disease visible and form the basis for the explanatory capacity to jump from one context to another in a supremely local, cultural, or social way - they are a kind of empirical proof that a theory produced in a research laboratory under European or American supervision is valid anywhere that a disease can be associated with the presence of these agents. In short, worms and mosquitoes transmit diseases, and also theories and practices that supplant local knowledge. In addition, the production of poverty as an explanatory factor for the presence of pathogens in the tropics thus began to figure as a central element in policies governing life and the new colonisation. "Controlling the disease by controlling the patient is one way in which the project for the consolidation of tropical medicine strongly operated the expansion of colonialism in the 19th and 20th centuries" (Segata, 2016, p. 87).

In this view, tropical pandemics are explained much more by exoticising the natural environment's elements, such as climate, soil, fauna, and flora, than by human interventions in these parts of the planet (Sá, 2013; see also Duin, 2021, this issue). This vision's effect was to shift the problem of colonisation of the tropics to elements of the tropics themselves, making the harmful effect of European expansion on these environments invisible. As Sá notes:

the colonizing expansion of European countries brought about extreme social, environmental and epidemiological changes. The flow 
of people, introduction of animals and plants, engineering works, railroads, etc., were environmental and cultural interventions in biologically unknown spaces, which led to a series of imbalances and adaptations that changed the configuration of relationship interactions between parasites, hosts, and vectors (Sá, 2013, p. 71).

In the past and the present, pandemics, plagues and pestilences are not natural phenomena. The colonising force was called upon to tame the hostile nature of this sertão (wild area) of the world. The imperialism of agribusiness has converted tropical landscapes into vast fields of the cultivation of transgenic monocultures or pig farms with their digestive atmospheres and contaminated living waste (Lapegna 2016; Blanchette, 2020; Segata, 2021, this issue). The point is, as noted by Ferdinand (2019), that the debate about tropical pandemics, plagues, and pestilence needs to be guided by the intersection of two agendas that have little crossed - one about the Anthropocene, the other about post-colonialism. And this raises the question, how can we think about the profound transformations of tropical ecologies and their devastating consequences without recognising the centuries of extraction, slavery, patriarchy, and destruction?

\section{Diseased Infrastructures - Africa}

In the public imagination, tropical Africa has remained the "dark continent", as popularised by British explorer and naturalised American Henry M. Stanley in 1878; "the heart of darkness", an expression coined by Polish-English novelist Joseph Conrad in 1899; and the "diseased continent". The theory of acclimatisation constructed the tropics as a space of death because of the hot climate and infectious diseases (see Ngalamulume, 2021, this issue). It assumed geographical determinism and did not consider the link between colonial exploitation and colonial pathologies; between international trade and the spread of cholera, yellow fever, and bubonic plague; between the construction of roads and railways and the spread of trypanosomiasis and smallpox; and between industrialisation, rural poverty, and tuberculosis.

The image of tropical Africa as an infectious continent, which saturated colonial and missionary discourses, has became entrenched since the 1970s as the continent has been repeatedly struck by outbreaks of new infectious diseases and the re-emergence of old diseases. The short-lived democratic experiments following the decade of African independence, the instauration of military regimes, personal rule, patronage politics and corruption, weakened the health infrastructure. Rural poverty and deforestation exposed people to the Ebola virus disease in Mobutu's Zaire (today Congo DRC) in 1976, the first of several haemorrhagic Ebola outbreaks that would hit 
several countries. The hunting, killing, and consumption of chimpanzees in the rainforest facilitated the cross-species transmission of Simian Immunodeficiency Virus (SIV) to humans. The virus adapted itself within its human host and became HIV-1. The crossover of another strain of SIV from monkeys to humans through the same process resulted in HIV-2. HIV caused AIDS, which was officially recognised in the 1980s. Southern Africa became the epicentre of the global AIDS epidemic due to its migrant labour system. It has since spread worldwide (see also, Sciortino, 2021, this issue).

The most recent haemorrhagic Ebola outbreaks occurred in densely populated urban centres in West Africa (Guinea, Liberia, and Sierra Leone) between 2014 and 2016 and produced thousands of cases and deaths. The three countries were post-conflict and failed states that had weak surveillance systems and poor public health infrastructure. The new Ebola outbreaks were contained thanks to a coordinated international response, but the anxiety they provoked only reinforced the negative images of tropical Africa as an infectious continent (see also, Clayton, 2021, this issue, pp. 12-13).

Tropical Africa has also witnessed the re-emergence and adaptation of old diseases, such as increased acute respiratory tract infections, gastrointestinal infections, tuberculosis, cholera, and malaria. Several factors have played an important role in both the emergence and re-emergence of diseases, these include: the ongoing destruction of the rainforest, global warming, migration, international travel, the circulation of commodities, poverty and social inequality, poor governance, and war and famine.

This negative imaginary of tropical Africa - and the tropics worldwide - is constantly reproduced. It infects the movie industry, social media, the political rhetoric of world leaders, the philanthropy industry, and educational systems.

\section{Tropical articulations: Pandemic, Plague, Pestilence}

As can be seen through this short sampling, the range of topics, disciplinary persuasions and tropical settings that can be called upon to illuminate notions of pandemic, plague, pestilence and the tropics is heterogeneous. And this is likewise reflected in the papers collected together in this Special Issue which address such varied richness through: poetry, cultural geography, philosophy, anthropology, science and technology studies, cultural studies, development studies, cultural history, urban studies, ethnographies, zombie film analysis and speculative fiction. 
The geographic reach of the papers is likewise richly diverse. Some papers have drawn out the intertwined relations between geographic zones, for instance the Tropics as situated always and already in relation to the temperate regions, especially the United Kingdom as a former colonial metropole; and in another paper the imaginary of the tropics from a European perspective (set in the Caribbean) is put into relation with a different imaginary emanating from the tropics of Thailand in Southeast Asia. Other papers that arise from Southeast Asia are located within the milieu of the Greater Mekong Subregion, which necessitates unimagining those borders between Cambodia, Laos, Myanmar, Thailand, Vietnam and southern China that were dawn during colonialism. Similarly, the Philippines, as another region in Southeast Asia, requires us to think beyond one place and instead use an archipelagic imaginary. Islands are also imaginative spaces, and the large island of Borneo (especially the state of Sabah) is encountered in two papers, one as colonial past and the other as speculative future. Likewise, the vastly dispersed islands of the Pacific require thinking not so much as individual islands, but through their oceanic connections, as well as contemplating the particular allure that the island of the Marquesas holds in AngloEuropean imagery of the South Pacific. Several papers address aspects of pandemic on the Indian Subcontinent, from evoking the state of India as a whole, to focusing on specific regions, such as Goa as a contemporary post-colony and vacation playground, or the $20^{\text {th }}$ century northeast Ganges deltaic plains. In the Americas papers address the industrialised landscape of contemporary southern Brazil and delve into the Indigenous history of northern Amazonia. Cities are also presented in this Special Issue, from the colonial city of Saint-Louis-du-Sénégal on the West coast of Africa across to the City of Miami in southeastern Florida during COVID-19.

We open this collection of papers with a poem. This is fitting, for poetry allows an immediacy of affect. The felt experience of the current pandemic, which has existed throughout the period of this Special Issue - from conception to publication surrounds all of us. The poem is followed by a selection of articles that put COVID-19 discourses under critical analysis from various philosophical angles and research methodologies. Then, delving back in history, several papers articulate waves of pandemics, plagues and pestilence investigated from the recent past, further back to colonial documentations, and further still, to Indigenous accounts articulated through mythology and ritual performance. The cultural history of epidemics is also evidenced in this collection through the close reading of literature, whether of European imaginaries or local articulations. Fiction, in fact, offers an extremely nuanced insight into pandemics, plagues and pestilence in association with tropicality. Film offers immediate affectivity and the zombie genre is revealing, while future scenarios from speculative fiction allow us to begin to see elsewhere and otherwise. 


\section{No Wild Iris - A Philippines Poem}

Christian Jil Benitez, in his poem No Wild Iris moves us into the quotidian experiences of the pandemic during the "longest lockdown in world history" (2021, p. 42). The poem allows us to reflect on our own situated experiences, while recognising in Benitez's evocations many shared experiences both within the tropics and across the world. Poetry also serves to draw us away from the overload of abstract statistics that have dramatically imbued life during COVID-19 (although the addictive qualities of statistical real-time graphs of coronavirus trackers is also a very real experience) to explore the nuances of this long stretch of homogenous and empty time. Benitez's poem is set mainly in the Philippines and he draws on qualities of archipelago consciousness (Carter, 2013) that draw into his field of articulation vignettes from media, politics and ecology. The poem also draws on, and softly inverts, feelings arising from Louise Glück's poem "The Wild Iris" which won the Nobel Prize in 2020, the same year as the pandemic lockdown. In tribute to Gluck, who writes, "At the end of my suffering/there was a door", Benitez opens his poem in resonance: "At the end of the world, there was barely a window./In fact there weren't many holes./For the longest time, we've learned how to stay indoors, shut ourselves/from ourselves." (2021, p. 43).

\section{Tropicality and the Choc en Retour of Covid-19 and Climate Change}

In his article, "Tropicality and the Choc en Retour of Covid-19 and Climate Change" (2021), Dan Clayton undertakes a rich philosophical exploration of tropicality and climate change through Aimé Césaire's ideas regarding the choc en retour, the boomerang effect of Western colonisation, and la quotidienneté barbaries, its daily barbarisms. Through this lens, Clayton unfolds media stories of COVID-19 in the United Kingdom. His emphasis is on the unravelling of binaries as the interrelation of the temperate tropical imaginaries become more pronounced due to aberrations and excesses of epidemic diseases and extreme weather events - imaged as tropical encroach into the temperate zone and the former metropole of colonialism. As Clayton states, the "temperate/tropical opposition has been conceived foremost in environmental terms, historically through capitalist and colonialist expansion and exploitation, and with factors of climate and disease, and health and hygiene, paramount" (2021, p. 55) His exploration has a rhizomatic feel as he threads tendrils of science, theory, politics and media in order to explore the sensibilities of tropicality and its associations with 'normal' and 'pathological', 'immunity' and 'susceptibility', as they are perceived and experienced through the crises of the novel coronavirus pandemic and climate change in temperate world. 


\section{COVID-19 Ecologies in the Global Meat-Processing Industry in Brazil}

Jean Segata, Luiza Beck and Luísa Muccillo argue that COVID-19 zoonosis ecologies go beyond exotic wet markets, and draw attention to the global meat-processing industry with an ethnographic study set in southern Brazil. Their article, "Beyond Exotic Wet Markets: COVID-19 Ecologies in the Global Meat-Processing Industry in Brazil" (2021) is a more-than-human anthropological and science and technology study in which the authors argue that the global meat processing industry involves close encounters between humans, animals, toxic chemicals, organic waste, and dangerous work conditions. They are ecologies, and they are unhealthy - coexistence, infection, risk, and death are always involved. As the authors state: "A pandemic is more than just a virus; it is a multispecies event. It involves humans, institutions, artefacts, and technologies, as well as animals, microorganisms, and environments. It also involves social injustices, precarious work, and environmental degradation" (2021, p. 95). In Brazil, high infection rates from the novel coronavirus were registered among meat industry workers and extended into their communities, causing the quarantine closures of several establishments. The emphasis on exotic discourses about wildlife consumption and wet markets serves to conceal how the large, but mundane, global agribusiness establishes unhealthy ecologies. The authors argue for a multispecies approach in the analysis and response to the COVID-19 pandemic; rather than the boundary-inducing overvaluation of conflict and contagion, they call for the establishment of integrated health policies for humans, animals, and environments.

\section{COVID-19 Pandemic Affect(abilities) in the Indian Context}

Abhisek Ghosal in his article, "Making Sense of Pandemic COVID-19 and its Affect(abilities) in the Indian Context" (2021), argues that the notion of illness is fluid in nature and its operations in the body are rhizomatic. Ghosal undertakes a philosophical investigation into the very being of dis-ease and sets his paper within the emergence of COVID-19 in India. Acknowledging that the pandemic has caused "historical ruptures" at a global scale, the author is interested in how the disease has especially affected the 'usual' ways of living of marginalised people in India, including how migrant labourers have had to adapt to severe pandemic consequences. He seeks to problematise the narrative of what illness is, arguing that we need to think of illness in terms of a multiplicity of disorder and an intra-corporeal otherness to healthiness. He states that: "the "being" of illness has to be understood in terms of "being with", for illness cannot be studied in isolation. Illness interacts both with intersubjective factors including contagion, physical proximity, and so on, and intrasubjective factors featuring causal connectivity between bodily organs, supply of neuronal stimuli, cognitive responses, etc" (2021, p.117). Ghosal seeks to cause his reader to reflect on the diverse affect(abilities) of the novel coronavirus pandemic - in India, and beyond. 


\section{Running Naked and Unmasked in Goa: Pleasure in the Pandemic}

Beginning with a self-promotional Instagram photograph of an Indian celebrity running naked and unmasked on a Goa beach during the COVID-19 pandemic, Benedito Ferrão takes the reader on a finely grained historical exploration of naked exposure across Indian advertising, filmmaking, and tourism. Of concern to the article is the tropical setting of Goa which serves as a pleasure periphery to India, which annexed the region in 1961. As the author articulates: "Indeed, it is Goa, or some skewed idea of it, that apparently makes it possible for visitors to act differently in the tropical locale than they would elsewhere" (2021, p.135). "Running Naked and Unmasked in Goa: Pleasure in the Pandemic" (2021), thus seeks to understand how Goa has been positioned in the imagination as a destination for self-gratification - an imaginary that was once the domain of hippies, but is now that of the Indian middleclass. Goa's economy remains particularly dependent on tourism, and the author investigates how this overexposes local people to the pandemic disease and death, and interrogates what is left unrevealed by the neoliberal economic imperative that renders some locales as holiday destinations even in the midst of a pandemic.

\section{Miami in Transformation during the COVID-19 Pandemic}

In their article "Miami in Transformation during COVID-19 Pandemic: A Participatory Visual Culture Analysis" (2021), the research team of Kaila Witkowski, John Vertovec, Natália Marques da Silva, Raymond K. Awadzi, Farah Yamini, Nelson Varas-Díaz, Mark Padilla, Sheilla Rodriguez Madera, Armando Matiz Reyes and Matthew Marr, draw on data collected during a digital participatory photographic project that was implemented in July 2020 - a couple of months after the announcement that novel coronavirus had reached pandemic proportions and was rapidly spreading throughout the USA. Their article shows how COVID-19 transformed the city of Miami, and how this also relates to Florida's subtropical location. The researchers point to the city's unique demographic: full-time residents of various backgrounds, including many first generation migrants from Latin America and the Caribbean; part-time and elderly residents escaping northern American winters; and tourists of national and international backgrounds - including university students on party vacations. Miami is impacted by the novel coronavirus disease in specific ways. The research team has drawn on concepts of visual culture analysis and disaster literature to analyse how the pandemic transformed the everyday lives of the people living in the city. Through an inductive thematic analysis of participants' photographs and supporting comments, the researchers unveiled that pandemic transformed not only everyday life and their concomitant needs, but also lead to recognition of privilege and an awareness of the needs of people in vulnerabilities circumstances. As the researchers state: "It is precisely because visual culture can highlight shared experiences that makes this 
approach an important tool in understanding complex social problems like disasters, epidemics and pandemics" (Witkowski et al., 2021, p.159).

\section{Learning from Past Funding Initiatives and their Dismissal in Southeast Asia}

Lia Sciortino takes us into the recent past as she examines philanthropic funding of previous efforts to control emerging infectious diseases in the Greater Mekong Subregion, which comprises areas of mainland Southeast Asia and southern China. In her article, "COVID-19: Learning from Past Funding Initiatives and their Dismissal in Southeast Asia" (2021), she articulates how American foundations and other likeminded donors identified the risks associated with zoonotic infections in the early 2000s. This included Betacoronaviruses, the same family of viruses that are causing the current COVID-19 pandemic. Initial funding efforts were followed by bilateral and multilateral donors investing even greater resources. Sciortino's analysis reviews both published and unpublished documents as well as offering critical insights based on her long experience as a foundation professional. Although two decades ago foundations had played an integral role in advancing a transdisciplinary agenda to better understand and respond to new emerging disease threats, over the last decade funding initiatives declined in both value and research intensity. She argues that this resulted in philanthropic foundations, and the development aid community, finding themselves unprepared for the current pandemic. Sciortino calls for an assessment of the effectiveness and strategic value of funding approaches to newly emerging diseases. She furthermore argues that the current crisis "alerts us to the fact that it is imperative that health - understood as socially determined and not just as a biomedical issue - and health care, gain greater relevance in international funding (and government agendas)" (2021, p.194).

\section{Governing Alcohol and Disease in the Forests of British North Borneo}

In David Saunders' article "“State of Intoxication”: Governing Alcohol and Disease in the Forests of British North Borneo" (2021), tropical imaginaries intertwine with colonial imaginaries. Set in British North Borneo (present day Sabah), during the 1920s and 30 s, the paper explores a range of documents as it seeks to elucidate how the tropics and Borneo - which lay at the edge of empire - were portrayed as fundamentally diseased and delinquent. Saunders focuses on issues of alcohol consumption, disease and public health - revealing their interrelation and, in the case of alcoholism, how this disease was projected onto indigenous communities by colonial administrators. The documentation on alcohol consumption of the time was extensive and ranges from literature to colonial memoranda. As the author states, from: "whisky and gin pahit-drinking bureaucrats of William Somerset Maugham's 'Before the Party'...to the colonial reports that poured scorn over alleged sightings of "native" babies being fed alcoholic tapai...the purported perils of alcohol garnered significant 
attention" (Saunders, 2021, p. 203). This emphasis contrasted with colonial indifference to substantial public health issues as epidemic outbreaks, including malaria, influenza, measles and amoebic dysentery, decimated indigenous populations - especially the marginalised Murut of the island's jungle interiors. Saunders draws on a range of sources, from colonial reports to indigenous oral tradition, in order to show how the British North Borneo Company, under economic stagnation, downplayed public health infrastructure and medical aid and instead amplified racist notions regarding alcohol addiction among the indigenous peoples. The legacies of this commercial-colonial system are still felt in Sabah, as the region continues to experience social, economic and health pressures - including during the COVID-19 pandemic.

\section{Medical Knowledge, and Stigmatisation in Saint-Louis-du-Sénégal, Africa}

Kalala Ngalamulume's paper "'Pestilential Emanations', Medical Knowledge, and Stigmatisation in Saint-Louis, Senegal, 1854-1920" (2021), is concerned with the underlying factors that instigated changes in the urban design of Saint-Louis, the capital of colonial Senegal. During the colonial period, and in the aftermath of epidemic diseases, urban design was transformed from racial coexistence to residential segregation. Ngalamulume documents in detail how French doctors conceived, through colonial medical knowledges ranging from miasma to germ theories, the region as a diseased environment and indigenous Africans as infectious agents. He concentrates "on the ways in which the colonial doctors conceptualised Senegal, and Senegambia, as a tropical land full of dangers, stigmatised the Africans as carriers of pathogens and thus a threat to the Europeans' health, and framed outbreaks of yellow fever epidemics as the key justification for the removal of the urban poor from the city centre" (2021, pp.229-230), and later from the city-island. Instrumental in these long processes of urban transformation were seemingly technocrat hygienic measures such as waste removal, the closure of cemeteries, and the imposition of new building codes. However, the author reveals the racialism under the objective discourse, and how it impacted the urban landscape of Saint-Louis, Senegal.

\section{Historic Epidemics and Resilience in Northern Amazonia}

Renzo Duin's paper takes the reader to Eastern Guiana - Suriname, French Guiana, and Brazilian Amapá - as he uncovers archival and historical sources that give eyewitness accounts of the epidemic waves of contagious diseases that impacted the Cariban-speaking communities of the region. His ethnographic concern is to demonstrate how Amazonian Indigenous Peoples, over a period of 550 years, have combatted emergent epidemic diseases. "Kuwamai: Historic Epidemics and Resilience of Cariban-Speaking Peoples, Northern Amazonia" (2021), "reveals their 
innovative responses to epidemiological crises related to epidemic viral diseases with flu-like symptoms, and focuses on what the Wayana people call "kuwamai", a specific kind of tïlëkhem (epidemic)" (2021, pp. 248-249). The paper includes previously unpublished journal entries by the Governor of Suriname during an outbreak of smallpox over the year 1743-1744; it includes rare 19th and 20th century historical accounts; and articulates an original interpretation of Wayana oral history - which is postulated to tell of the spread of the first viral disease in Amazonia in 1542. The paper argues that Wayana responses to the current COVID-19 pandemic arise from their long historical indigenous etiology.

\section{Epidemic and Disease in Anglo-Colonial Writings of the South Pacific}

Chrystopher Spicer in his article "Weep for the Coming of Men: Epidemic and Disease in Anglo-Western Colonial Writing of the South Pacific" (2021), explores a cultural history of the 'fatal impact' Westerners had on Pacific peoples through an analysis of the travel novels by the writers: Herman Melville, Robert Louis Stevenson, Louis Becke, Jack London, and Fredrick O'Brien. As Spicer notes, due to the "isolated nature of Pacific island geography, historic contact between Islanders and Europeans had been minimal prior to Captain Cook's three voyages and subsequent numerous landfalls throughout the Pacific, and Islanders had no immunity to many contagious diseases such as measles, smallpox, tuberculosis, syphilis, and leprosy. The key to the West's ability to dominate and conquer, then, may not have lain in who they were, but in what they brought with them: in this case, microbes" (2021, p. 276). It is particularly remarkable that each of the travel writers visited the Marquesas Islands, and this small archipelago became for these authors a microcosm of the epidemiological devastation that was being witnessed across the remote South Pacific islands and the consequent catastrophic death tolls. Instead of the tropical paradise these authors desired, they experienced a diseased landscape fatally ravaged by contact with Western 'civilisation'. The writers were of their time and Social Darwinism and extinction discourse permeates their views. However, unlike the distanced perspective of the Victorian-era traveller, as analysed by Mary Louise Pratt, these writers were each penetrated by the horror around them, forcing them to write from felt experience as they bore witness to the impact of Western society and its diseases on the physical and mental health of Pacific Islanders.

\section{Pandemics in $20^{\text {th }}$ Century India through Hindi Literature}

Prachi Priyanka, turns to Hindi literature to delve into authors' perspectives as they bore witness to pandemics of plague, influenza, smallpox and cholera that swept across India - and especially the monsoonal Ganges delta. Her paper, "Impacts of Pandemics in $20^{\text {th }}$ Century India: Through the Lens of Hindi Literature" calls on the 
stories penned by Phanishwar Nath Renu, Suryakant Tripathi Nirala, Munshi Premchand, Bhagwan Das, Pandey Bechan Sharma, and Hari Shankar Parsai, as they describe the suffering - physical and psychological - wrought by rampant diseases that killed people in the millions. As she states, pandemic literature "takes us beyond statistics of deaths, devastations, and degrees of spread - to show its impact on the lives of families, friends and neighbours of the infected and dying. These stories in all ages have explored lethal infectious diseases, inviting readers to experience the trauma of millions impacted by the pandemics that destroyed towns and left generations scarred and scared" (2021, pp. 298-299). Priyanka notes that the tropical regions of the Indian Ocean were conceived of as zones of disease, and India rendered "a quagmire of diseases and epidemics" (2021, p. 295), and that it was always the poorest who suffered outbreaks of pestilence to a greater degree.

\section{Pandemics and Zombies: Tropical Imaginaries, Cinematic Cosmologies}

Milan Kroulík opens his paper with the following invitation: "imagine two films, from different eras and film-making traditions. One ends with terrifying visions of an unstoppable disease transforming all human bodies at the very centre of empire. The other closes with a series of scenes: slowed down bodies, dream machines, communal sports in transforming landscapes - and an uncertain gaze into the distance" (2021, p. 316). This placing of the reader within these filmic scenes is important, for the author's subtext is an argument for the significance of the cinematic image to understanding and living with bio/socio/political issues. In "Pandemics and 'Zombies': How to Think Tropical Imaginaries with Cinematic Cosmologies" (2021), Kroulík discusses notions of the tropics, disease, 'zombies' bodies and heteronomy with philosophical articulations of Christian-secular and Buddhist-Animist cosmologies. He does this through an interweaving with two films: Zombi 2, a EuroAmerican imagining of the tropics from a temperate zone and Christian tradition; and Cemetery of Splendor, a Thai film that is an engagement from within the tropics and a Buddhist imaginary. He argues that the zombie as a site of ontological uncertainty and rendered differently according to cultural and ideological imaginaries - allows us to think the problem of a pandemic with notions of subjectivity and corporeality.

\section{Neotropical Imaginings from a Postpandemic Colony}

In the finale paper of this collection, Christina Yin's flash fiction piece, "A Rush Hour Ride on the Dwarf Planet: Neotropical Imaginings from a Postpandemic Colony" (2021), takes us into the speculative far future as she weaves dystopian outer space scenes of a freezing winter, with advertisements of utopian tropical paradise holidays on the island of Borneo, back on a resuscitated Earth. As the author informs us, the great world pandemic of 2020 never ended, and as the virus persistently mutated, humans raced to get to space. As Yin tells us: "The story was - well, the history books 
confirmed this - that KE's ancestors had won a spot in the lucky draw and were among the first colonists on the Moon. Now, many generations later, KAE was in the far reaches of the solar system. You couldn't deny that the human race was a species of colonists at heart" (2021, p. 342). Yin weaves harsh futuristic scenarios with languid scenes of tropical landscapes and waterscapes filled with rainforests, orangutans, the giant Rafflesia flower and whale sharks. This is a story that hints of the interrelations between environmental destruction and pandemic, of human technological capability and human expulsion.

\section{Pandemic Futures}

And thus we close the collection of papers for this Special Issue with a futuristic story. This, like our opening with a poem, is fitting, for the novel coronavirus pandemic is certainly not yet ended; while historical pandemics, plagues and forms of pestilence as they are imagined through tropicality appear without end as they are persistently reanimated in the present. It is also fitting to end the collection with a piece from speculative fiction, for this draws our attention to the way in which each of these papers offer us ways in which to imagine other versions of the world - each paper as a medium that calls for, and articulates, alternative social and political aspirations, ones that involve humans, viruses, diseases, animals, environments and technologies in more-than-human-worlds. 


\section{References}

Ball, A. (Prod.). (2008-2014). True blood [Television series]. HBO.

Bellatin, M. (2002 [1994]). Beauty Salon. City Lights Publishers

Benitez, C.J. (2021). No Wild Iris. eTropic: electronic journal of studies in the tropics 20 (1), 42-53 http://dx.doi.org/10.25120/etropic.20.1.2021.3773

Blanchatte, A. (2020). Porkopolis: American animality, standardized life, and the factory farm.

Duke University Press. https://doi.org/10.1515/9781478012047

Brabin, C. (Director) (1932). The Mask of Fu Manchu [Film]. Cosmopolitan Productions.

Carter, P. (2013). Tropical Knowledge: Archipelago Consciousness and the Governance of Excess. eTropic: electronic journal of studies in the tropics, 12 (2), 79-95. https://doi.org/10.25120/etropic.12.2.2013.3334

Cho, I-H. (Director) (2020) \#Alive [Film]. Zip Cinema \& Perspective Pictures.

Clayton, D. (2021). Tropicality and the Choc en Retour of Covid-19 and Climate Change. eTropic: electronic journal of studies in the tropics 20 (1), 54-93. http://dx.doi.org/10.25120/etropic.20.1.2021.3787

Creed, B. (2011). Tropical Malady: Film \& the Question of the Uncanny Human-Animal. eTropic: electronic journal of studies in the tropics 10, 131-140. https://doi.org/10.25120/etropic. 10.0.2011.3414

De Kosnik, A. (2015). The Mask of Fu Manchu, Son of Sinbad, and Star Wars IV: A New Hope. Techno-Orientalist Cinema as a Mnemotechnics of Twentieth-Century U.S.Asian Conflicts. In Roh, D.S., Huang, B., \& Niu, G.A. (Eds). TechnoOrientalism: Imagining Asia in Speculative Fiction, History, and Media (pp. 89-100). Rutgers University Press. https://doi.org/10.36019/9780813570655-008

Dillon, R. \& Lundberg, A. (2017). Vampires in Video Games: Mythic Tropes for Innovative Storytelling. eTropic: electronic Journal of Studies in the Tropics, 16(1), 46-67. https://doi.org/10.25120/etropic.16.1.2017.3578

Doucleff, M. (2021). WHO Points to Wildlife Farms in Southern China as Likely Source of Pandemic. NPR. https://www.npr.org/sections/goatsandsoda/2021/03/15/977527808/who-points-towildlife-farms-in-southwest-china-as-likely-source-of-pandemic

Duin,R.S. (2021). Kuwamai: Historic Epidemics and Resilience of Cariban-Speaking Peoples, Northern Amazonia. eTropic: electronic journal of studies in the tropics 20 (1), 247-272. http://dx.doi.org/10.25120/etropic.20.1.2021.3759

Echenberg, M. (2007). Plague Ports: The Global Urban Impact of Bubonic Plague, 18941901. New York University Press.

Eiseman, F.B. Jr. (1990). Bali Sekala \& Niskala: Essays on Religion, Ritual, and Art. Tuttle Publishing.

Eisenberg, M. \& Mordechai, L. (2020). The Justinianic Plague and Global Pandemics: The Making of the Plague Concept. The American Historical Review 125 (5), 1632-1667. https://doi.org/10.1093/ahr/rhaa510

Ferdinand, M. (2019). Une écologie décoloniale: penser l'écologie depuis le monde coloniale. Seuil. https://doi.org/10.3917/pro.375.0052

Ferrão, R.B. (2021). Running Naked and Unmasked in Goa: Pleasure in the Pandemic. eTropic: electronic journal of studies in the tropics 20 (1), 134-156. http://dx.doi.org/10.25120/etropic.20.1.2021.3789

Fearnley, L. (2020). Virulent Zones: Animal Disease and Global Health at China's Pandemic Epicenter. Duke University Press. https://doi.org/10.1515/9781478012580

Flint, S. (Ed.) (2020). Unmasked: Reflections On Virus-Time. Heliconia Press

Foucault, M. (1986). Of Other Spaces [Original lecture 1967; Orig pub 1984; Trans. J. Miskowiec]. Diacritics, 16, 22-27. https://doi.org/10.2307/464648 
Ghosal, A. (2021). Making Sense of Pandemic COVID-19 and its Affect(abilities) in the Indian Context. eTropic: electronic journal of studies in the tropics 20 (1), 115-133. http://dx.doi.org/10.25120/etropic.20.1.2021.3780

Greenblatt, S. (2020, May 17). What Shakespeare Actually Wrote about the Plague. The New Yorker. https://www.newyorker.com/culture/cultural-comment/whatshakespeare-actually-wrote-about-the-plague

Harris, C. (2009). A touch of dead. Sookie Stackhouse: The complete stories. ACE Books. Herrera, Y. (2016, [2013]). The Transmigration of Bodies [Trans. L. Dillman]. And Other Stories.

Infectious Historians. (2020, Sep 26). Episode 28: The Great Hanoi Rat Hunt with Michael Vann. (Speaker, Vann, M.G. with Hosts, Eisenberg, M. \& Mordechai, L.) [Podcast]. https://anchor.fm/infectioushistorians/episodes/Episode-28-The-Great-Hanoi-RatHunt-with-Michael-Vann-ek5pl5/a-a3bjlf5

Kroulík, M. (2021). Pandemics and 'Zombies': How to Think Tropical Imaginaries with Cinematic Cosmologies. eTropic: electronic journal of studies in the tropics 20 (1), 315-339. http://dx.doi.org/10.25120/etropic.20.1.2021.3768

Lapegna, P. (2016). Soybeans and power: genetically modified crops, environmental politics, and social movements. Oxford University Press. https://doi.org/10.1093/acprof:oso/9780190215132.001.0001

Lee, G. B. (2021). \#chinesevirus: The Long Racism that Lurks Behind COVID-19. Postcolonial Politics. March 26. Retreived from https://postcolonialpolitics.org/chinesevirus-racism-behind-covid-19/

Lima, N. T. \& Hochman, G. (2004). 'Pouca saúde e muita saúva': sanitarismo, interpretações do país e ciências sociais. In Hochman, G. \& Armus, D. (Eds). Cuidar, controlar, curar: ensaios históricos sobre saúde e doença na América Latina e Caribe (pp. 493-534). Editora FIOCRUZ. https://doi.org/10.7476/9788575413111

Lobato, M. (2019). Urupês. La Fonte.

Logan, J. (2021, April). Interview. Ubud, Bali.

Löwy, I. (2006). Vírus, mosquitos e modernidade: a febre amarela no Brasil entre ciência e política. Fiocruz. https://doi.org/10.7476/9788575412398

Lundberg, A. (2020). Balinese Dancer wearing a Gas Mask: Climate Change and the Tropical Imaginary. [Climate Change, COP26 and the Crucible of Crisis Special Issue]. Scottish Geographical Journal RSGJ. 136 (1-4). https://doi.org/10.1080/14702541.2020.1858589

Lundberg, A., Osborne, R., Ancuta, K. \& Stasiewicz-Bienkowska, A. (2019). Tropical Gothic: Literary and Creative Works. eTropic: electronic journal of studies in the tropics, 18 (2), 1-15. http://dx.doi.org/10.25120/etropic.18.2.2019.3701

Lynteris, C. (2018) Plague Masks: The Visual Emergence of Anti-Epidemic Personal Protection Equipment, Medical Anthropology 37 (6), 442-457 https://doi.org/10.1080/01459740.2017.1423072

Marchetti, G. (1993). Romance and the "Yellow Peril": Race, Sex, and Discursive Strategies in Hollywood Fiction. University of California Press.

Márquez, G.G. (2003 [1985]). Love in the Time of Cholera [Trans. E. Grossman]. Vintage International.

Maxmen, A. (2021, March 30). WHO report into COVID pandemic origins zeroes in on animal markets, not labs. Nature News. https://doi.org/10.1038/d41586-021-00865-8

Mayer, R. (2012). Image power: seriality, iconicity and The Mask of Fu Manchu, Screen, 53 (4), 398-417, https://doi.org/10.1093/screen/hjs036

Ngalamulume, K. (2021). 'Pestilential Emanations', Medical Knowledge, and Stigmatisation in Saint-Louis, Senegal, 1854-1920. eTropic: electronic journal of studies in the tropics 20 (1), 226-246. http://dx.doi.org/10.25120/etropic.20.1.2021.3792 
Peterson, J.F. \& Terraciano, K. (Eds) (2019). The Florentine Codex: An Encyclopedia of the Nahua World in Sixteenth-Century Mexico. University of Texas Press.

Pratt, M. L. (1992). Imperial Eyes: Travel Writing and Transculturation. Routledge. https://doi.org/10.4324/9780203163672

Priyanka, P. (2021). Impacts of Historic Pandemics in India: Through the Lens of $20^{\text {th }}$ Century Hindi Literature. eTropic: electronic journal of studies in the tropics 20 (1), 294-314. http://dx.doi.org/10.25120/etropic.20.1.2021.3791

Rice, A. (1976). Interview with a vampire. New York, NY: Ballantine Books.

Roh, D.S., Huang, B., \& Niu, G.A (2015). Technologizing Orientalism. In Roh, D.S., Huang, B., \& Niu, G.A. (Eds). Techno-Orientalism: Imagining Asia in Speculative Fiction, History, and Media (pp. 1-20). Rutgers University Press. https://doi.org/10.36019/9780813570655-002

Sá, M. R. (2013). Migração e saúde nos trópicos. In Nodari, E. S. \& Correa, S. M. S. (Eds). Migrações e natureza (pp. 71-92). Oikos.

Saunders, D.R. (2021). "State of Intoxication:" Governing Alcohol and Disease in the Forests of British North Borneo. eTropic: electronic journal of studies in the tropics 20 (1), 202-225. http://dx.doi.org/10.25120/etropic.20.1.2021.3779

Sciortino, R. (2021). COVID-19: Learning from Past Funding Initiatives and their Dismissal in Southeast Asia. eTropic: electronic journal of studies in the tropics 20 (1), 182-201. http://dx.doi.org/10.25120/etropic.20.1.2021.3784

Segata, J. (2016). A doença socialista e o mosquito dos pobres. Iluminuras, 17 (42), 372-389. https://doi.org/10.22456/1984-1191.69998

Segata, J., Beck, L., \& Muccillo, L. (2021). COVID-19 Ecologies: The Case of the Global Meat-Processing Industry in Southern Brazil. eTropic: electronic journal of studies in the tropics 20 (1), 94-114. http://dx.doi.org/10.25120/etropic.20.1.2021.3794

Shepherd, P. (2018). The Book of M. William Morrow.

Serpell, N. (2019). The Old Drift. Hogarth.

Siu, L. \& Chun, C. (2020). Yellow Peril and Techno-orientalism in the Time of Covid-19: Racialized Contagion, Scientific Espionage, and Techno-Economic Warfare. Journal of Asian American Studies, 23 (3), 421-440. https://doi.org/10.1353/jaas.2020.0033

Spicer, C.J. (2021). Weep for the Coming of Men: Epidemic and Disease in Anglo-Western Colonial Writing of the South Pacific. eTropic: electronic journal of studies in the tropics 20 (1), 273-293. http://dx.doi.org/10.25120/etropic.20.1.2021.3783

Standaert, M. (2020, Feb 25). Coronavirus closures reveal vast scale of China's secretive wildlife farm industry. The Guardian.

https://www.theguardian.com/environment/2020/feb/25/coronavirus-closures-revealvast-scale-of-chinas-secretive-wildlife-farm-industry

'Vampire the Masquerade: Bloodlines' (2004) [video game]. Santa Monica, CA, Activision for PC.

Vann, M.G. (2020, July 10). Microsyllabus: Histories of Epidemic Disease. The Abusable Past. https://www.radicalhistoryreview.org/abusablepast/microsyllabus-histories-ofepidemic-disease/

Vann, M.G. \& Clarke, L. (2018). The Great Hanoi Rat Hunt: Empire, Disease, and Modernity in French Colonial Vietnam. Oxford University Press.

VOA (2021, April 13). WHO Calls for Halt to Sale of Live Wild Mammals in Markets. VOA news. https://www.voanews.com/covid-19-pandemic/who-calls-halt-sale-live-wildmammals-markets

Waugh, A. (2012 [1930]). Hot Countries: A Travel Book. Bloomsbury Reader.

Weerasathakul, A. (Director) (2004). Tropical Malady [Film]. GMMGrammy, TIFA, Kick the Machine \& Anna Sanders Films. 
Witkowski, K., Vertovec, J., Marques da Silva, N., Awadzi, R.K., Yamini, F. Varas-Díaz, N. Padilla, M. Madera, S.R., Reyes, A.M., Marr, M. (2021). Miami in Transformation during the COVID-19 Pandemic: A Participatory Visual Culture Analysis. eTropic: electronic journal of studies in the tropics 20 (1), 157-181. http://dx.doi.org/10.25120/etropic.20.1.2021.3772

WHO (2021, March 30). WHO-convened global study of origins of SARS-Cov-2: China Part. Joint WHO-China Study Team Report, 14 January-10 February. Joint Report. https://www.who.int/publications/i/item/who-convened-global-study-of-origins-of-sarscov-2-china-part

Yeon, S-H. (Director) (2020). Train to Busan Presents: Peninsula [Film]. Next Entertainment World, Red Peter Films, New Movie.

Yin, C. (2021). A Rush Hour Ride on the Dwarf Planet: Neotropical Imaginings from a Postpandemic Colony. eTropic: electronic journal of studies in the tropics 20 (1), 340344. http://dx.doi.org/10.25120/etropic.20.1.2021.3776

Zainudin, S. \& Krishnamoorthy, V. (Eds) (2021). The Lockdown Chronicles. Media Masters Publishing.

\section{Acknowledgements}

This Special Issue was drawn together under the time of COVID-19, and our academic colleagues and friends were affected by the novel coronavirus pandemic in multiple ways. Some were infected with COVID-19, some were experiencing the ongoing effects of long the coronavirus. All our colleagues were under increased, changing and challenging workloads. Several colleagues who expressed keen interest in submitting to the special issue had to withdraw due to workloads, pressing commitments, sick relatives, or lack of childcare when kindergartens closed down. Reviewers were under increased stress and we thank them for using their failing energy reserves in carrying out rigorous peer reviews of the papers collected together in this Special Issue.

Associate Professor Anita Lundberg is a cultural anthropologist. Her ethnographies - situated in Bali, Singapore, Malaysia and far Eastern Indonesia - explore the intertwinings of environment and culture through interdisciplinary studies of urban life, the cinematic city, neoliberal higher education, climate change street art, architecture and a garden of indigenous trees, and a whale hunting village. Anita has won awards and held international fellowships: LIA TransOceanik (CNRS, JCU, Collége de France); The Cairns Institute (TCl); Evans Fellow, Cambridge University, UK; Guest Researcher, Maison Asie-Pacifique, Université de Provence, France; Visiting Fellow, Institute of the Malay World and Civilization, National University Malaysia; and Anthropologist-in-Residence, Rimbun Dahan, Malaysia. She has published extensively in academic journals and edited numerous Special Issues. Anita has also curated exhibitions in NY, LA, Paris and Sydney, and her own research has been exhibited at the Australian National Maritime Museum, the National Art Gallery of Malaysia and Alliance de Française. Anita was a Post-Doctoral Fellow, Cambridge 
University, UK, she has a PhD in Anthropology, and an MA in Science \& Technology Studies. Contact: anita.lundberg@jcu.edu.au

Associate Professor Dr Kalala Ngalamulume is with History and Africana Studies at Bryn Mawr College in Pennyslvania, U.S.A. He is the author of several scholarly articles and book chapters on the social history of medicine, disease, and health in Senegal. $\mathrm{He}$ is also the author of Colonial Pathologies, Environment and Western Medicine in Saint-Louis-du-Senegal, $1867-1920$ (2012), and co-editor with Paula Viterbo of Medicine and Health in Africa: Multidisciplinary Perspectives (2010). He has published in the Journal of African History, Journal of West African History, Cahiers d'Études Africaines, Politique Africaine, History in Africa, African Economic History, Revue de Pédagogie Appliquée, Encyclopedia of African History, and Oxford Bibliographies Online. Kalala has a PhD in History, and an MA in International Affairs. Contact: kngalamu@brynmawr.edu

Associate Professor Jean Segata is with the Department of Anthropology at the Federal University of Rio Grande do Sul (Brazil), where he is the director of the NEAAT Centre for Animal, Environmental and Technology Studies. Recently, he was Craig Cogut Visiting Professor for Latin American and Caribbean Studies at Brown University. His teaching and research experiences intersect anthropology of science \& technology, health, and human-animal-environmental relations. Currently is the $\mathrm{PI}$ of the Rede Covid-19 Humanidades MCTI project. Contact: jeansegata@ufrgs.br

Associate Professor Arbaayah Ali Termizi is with the Department of English, Universiti Putra Malaysia. With a love for theatre, she has taken on the roles of creative advisor / producer of amateur play productions such as Les Misérables (2013), Beauty and the Beast (2013), The Great Gatsby (2014), Gormenghast (2015), Keris Laksamana Bentan (2018) and Zoom-ed: A Musical Showcase (2021) in addition to the staging of several of Shakespeare's plays prior to 2010. Her PhD thesis entitled Anthony and Cleopatra in the Eighteenth Century: Critical Observation of Shakespeare's Tragedy (2010) was published as a book, followed by A Midsummer Night's Dream: Shakespeare Appropriated in 60 Minutes (2013). In August 2020, another book titled Theatre for Life Workshop: Perspectives and Reflections which she co-edited was published as an initiative to promote an interest in theatre to the wider public in Malaysia. Arbaayah founded Theatre for Life Workshop (TFLW) with the aim to engage the community with pre-staging activities as a means to create awareness in contemporary social issues. She has been invited as a speaker, seminar leader and visiting scholar at both local and international conferences to talk about her work on preserving culture and heritage with theatre as a medium. Contact: arbaayah@upm.edu.my 
Dr Chrystopher J. Spicer has written extensively on Australian-Oceania and American literary and cultural studies in a number of books and journal articles. His latest book is Cyclone Country: The Language of Place and Disaster in Australian Literature (McFarland, 2020). Chrystopher is currently a cultural historian and a Senior Research Fellow (Adj) at James Cook University, Cairns, Queensland. Contact: chrystopher.spicer@jcu.edu.au 